Portland State University

PDXScholar

Summer 8-11-2017

\title{
Holocaust, Memory, Second-Generation, and Conflict Resolution
}

Leslie O'Donoghue

Portland State University

Follow this and additional works at: https://pdxscholar.library.pdx.edu/open_access_etds

Part of the Jewish Studies Commons, and the Peace and Conflict Studies Commons Let us know how access to this document benefits you.

\section{Recommended Citation}

O'Donoghue, Leslie, "Holocaust, Memory, Second-Generation, and Conflict Resolution" (2017). Dissertations and Theses. Paper 3785.

https://doi.org/10.15760/etd.5669

This Thesis is brought to you for free and open access. It has been accepted for inclusion in Dissertations and Theses by an authorized administrator of PDXScholar. Please contact us if we can make this document more accessible: pdxscholar@pdx.edu. 
Holocaust, Memory, Second-Generation, and Conflict Resolution

by

Leslie O'Donoghue

A thesis submitted in partial fulfillment of the requirements for the degree of

Master of Science

in

Conflict Resolution

Thesis Committee:

Barbara Tint, Chair

Amanda Smith Byron

Robert Jarvis Gould

Portland State University

2017 
(C) 2017 Leslie O'Donoghue 


\begin{abstract}
Ten Jewish second-generation men and women from metro Portland, Oregon were interviewed regarding growing up in the aftermath of the Holocaust. The American-born participants ranged in age from fifty-one to sixty-four years of age at the time of the interviews. Though the parents were deceased at the time of this study the working definition of a Holocaust survivor parent included those individuals who had been refugees or interned in a ghetto, labor camp, concentration camp, or extermination camp as a direct result of the Nazi Regime in Europe from 1933 to 1945.
\end{abstract}

A descriptive phenomenological approach was utilized. Eight open-ended questions yielded ten unique perspectives. Most second-generation do not habitually inform others of their second-generation status. This is significant to conflict resolution as the effects of the Holocaust are trans-generational. The second-generation embody resilience and their combined emphasis was for all people to become as educated as possible.

Keywords: Holocaust, Memory, Second-Generation, Resilience, Conflict Resolution 


\section{Dedication}

This thesis pays tribute to the incredible resilience of persecuted people. 
Acknowledgements

First of all, I must extend my gratitude to my family for their extraordinary support. My son, Curran O'Donoghue, is ever the light of my life, a magician, and the master of complex sentence structure. Roberta O'Donoghue, my mother, and Phil Butcher, my step-father, plus, my aunt Carolyn Charter, have done everything possible to uphold my success in researching and writing this thesis.

I would like to acknowledge the illuminating and sustaining guidance of my mentor Dr. Rachel Halfrida Cunliffe of Portland State University, without whom this endeavor may have never taken place. In addition, influential people have been two second-generation individuals, my thesis chair, Dr. Barbara Tint, and Dr. Amanda Byron, daughter of a Holocaust refugee. Plus, I appreciate the third person on my committee Dr. Robert Gould, director of the Conflict Resolution department from 1993-2015.

Finally, but by no means lastly, there is an incredible acknowledgement of gratitude to extend to the second-generation survivors who privileged me with the opportunity to listen to part of their life stories. My appreciation broadens throughout the Jewish community to all of the people who have assisted me in making connections with second-generation people, as well as, having offered profound insights. Specifically, I would like to thank Diane Koosed and Lauren Fortgang of Neveh Shalom and the Never Again Coalition for their unwavering enthusiasm, plus, Peter Wigmore of the Oregon Holocaust Resource Center for his generous spirit. 


\section{Table of Contents}

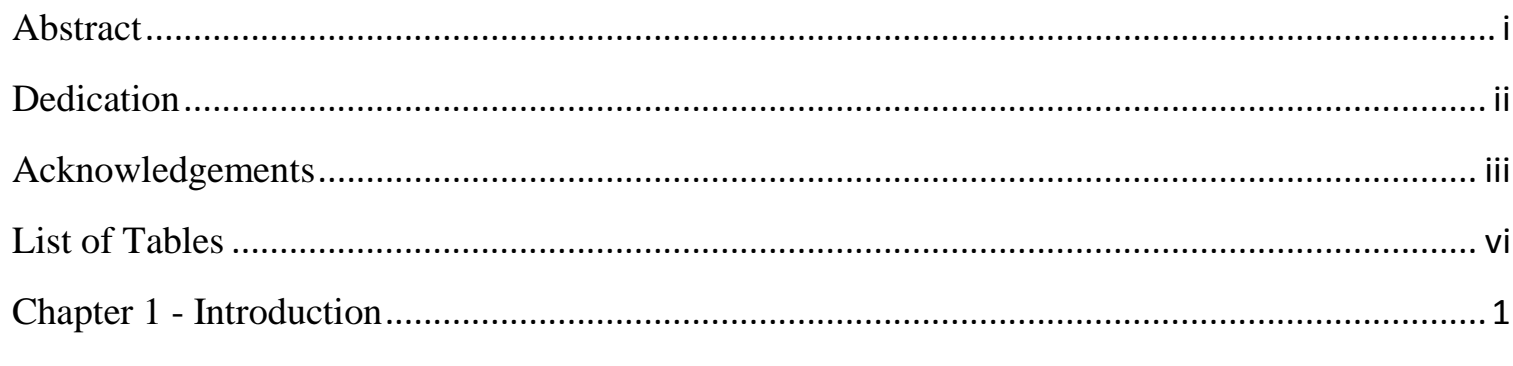

Primer on the Holocaust................................................................................... 2

The Compelling Nature of the Problem in Conflict Resolution ........................................... 3

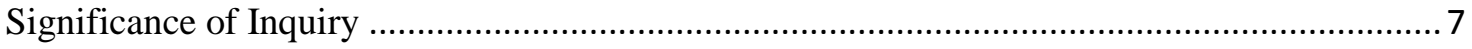

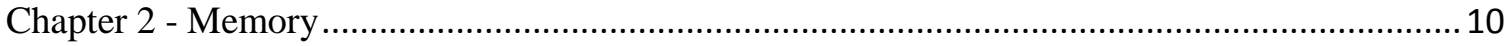

Memory and Conflict Resolution......................................................................... 15

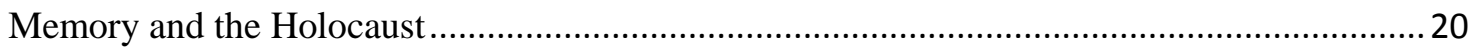

Memory and the Second-Generation ................................................................... 22

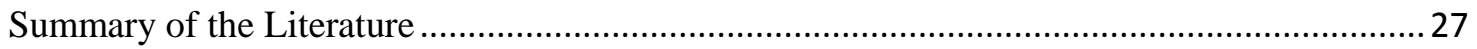

Chapter 3 - Methodological Process .......................................................................... 29

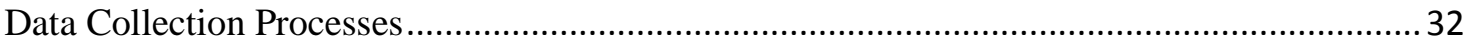

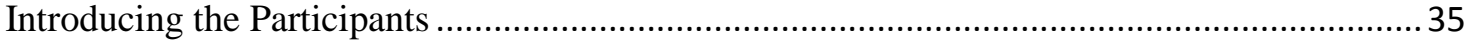

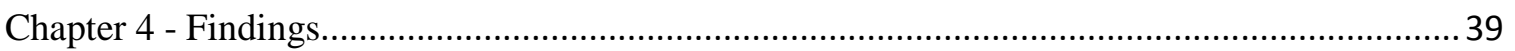

His Girlfriend's Phone Number.......................................................................... 39

"Hi, I'm Karen, I'm Second-Generation" .......................................................... 42

What We Lost: Family and Mementos ......................................................... 46

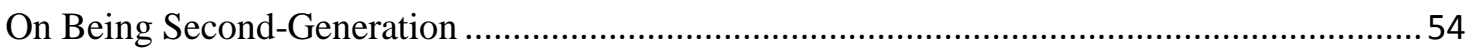

Sometimes It's Difficult, but I've Always Felt Honored ............................................61

Media and Memories ..................................................................................... 70

Speaking of God and The Jewish Tour ................................................................. 75

Education is Life Itself .................................................................................. 82

What Should Other People Know About Being Second-Generation?................................88

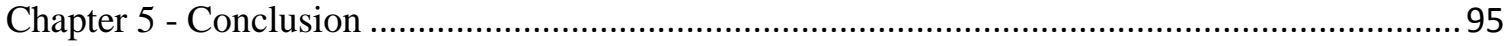




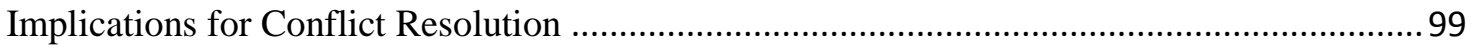

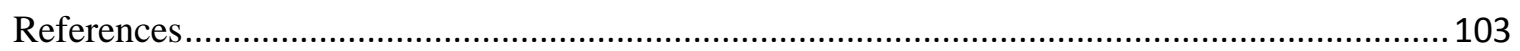

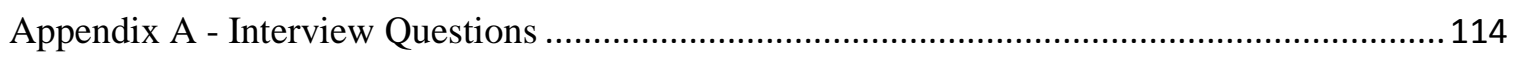

Appendix B - IRB Approved Consent Form - Video …...................................................... 115

Appendix C - IRB Approved Consent Form - Written ........................................................ 116 
List of Tables

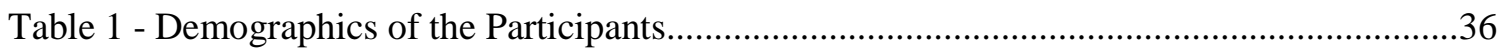


Holocaust, Memory, Second-Generation, and Conflict Resolution

"Without memory there is no future." -Dr. Sal Mangione

"Memory can be the weak flame of the struggle to remember, or the stable, enduring habits acquired over the long duration of relationships. Its loss is greatly feared, yet often we seek the therapeutic power of forgetting, It has sustained hidebound traditionalism in politics, but it has also been a weapon of liberation and a recognition of those who have been silenced or otherwise wronged. It has been used to justify great crimes, and yet it is central to the pursuit of justice."

-W. James Booth, Communities of Memory: On Witness, Identity and Justice (2006, p. ix)

\section{Chapter 1 - Introduction}

This paper is a phenomenological inquiry into the lives of ten secondgeneration participants to reveal Jewish Holocaust survivor's children's memories of growing up with Holocaust survivor parents. These children, now adults, are the second-generation. The working definition of a Holocaust survivor parent included individuals who had been refugees or interned in a ghetto, labor camp, concentration camp, or death camp, as a direct result of the Nazi Regime in Europe from 1933 to 1945 . The second-generation are living their entire lives in the aftermath of the Holocaust. Vivid images, deep emotions and physical sensations are what Kraft (2006) says are core memory. It is precisely this which is of interest here. How has the Holocaust impacted the second-generation? 
Primer on the Holocaust

The very word, "genocide," was coined by Raphael Lemkin to refer to the Holocaust in 1944. Berger (1997) notes he couldn't answer one of the most prolific questions asked by millions of people: "Why the Jews?" To date, this question has no satisfactory answer. Berger says, "The Third Reich's circle of victims kept increasing, but Jews were always at the center of this circle" (p. 120).

The Holocaust refers to the Nazi regime's persecution, torture, and murder of Jewish people. The Holocaust or Shoah [the Hebrew word for the Holocaust] destroyed lives. Alongside were the mass murders of the Roma, LGBTQ individuals, disabled persons, political prisoners and others. However, these deaths are not normally included in talk of the Holocaust which refers uniquely to the Jewish experience. Approximately twelve million people were killed with over half of those being Jewish people, 1.5 million Jewish children were among them. Underpinnings of the Holocaust began prior to 1933 through anti-Semitism and the Holocaust continued well past 1945 as many survivors were trapped in displaced persons (DP) camps waiting for years for visas out.

To study the Holocaust it is important to understand the origins of the concentration and death camp system and how early it began. Dachau, created from an old munitions factory, was the first, opened in 1933. The wrought iron gate had the slogan "Arbeit macht frei" or "work will make you free." Work did not lead to liberation as over 30,000 people were killed in Dachau. There were also ten other camps in Germany by 1933 for "preventive custody" with an 
approximate 25,000 inmates and by 1935 there were six more concentration camps throughout Germany with 10,000 people incarcerated (Dawidowicz, 1975, p. 75-76). By 1938, Buchenwald, Dachau and Sachsenhausen were intentionally enlarged to accommodate a planned influx of "slave labor" (Dawidowicz, 1975, p. 99). The slaves were largely Jewish, though all sorts of "criminals" and "undesirables" were incarcerated.

The 1933-forward timing of these camps is critically important in regard to the sheer breadth of the Nazi plans for the Jewish, Roma, homosexuals, disabled and others. It must be said the majority of nations, including the United States, severely limited the number of refugees accepted and/or ultimately closed their borders to the refugees. Obviously many people could not afford to flee, and even for some of those who did, such as those on the ship St. Louis (May/June 1939), were returned Europe by the United States where they subsequently perished. World War II began 1 September 1939, though the United States did not enter the war until the 7 December 1941 attack on Pearl Harbor.

\section{The Compelling Nature of the Problem in Conflict Resolution}

The current research and paper are being done through the auspices of the Conflict Resolution department, but this is not technically a textbook discussion of conflict resolution. From an academic stance we might look at conflict resolution on a continuum from wars of extermination-deterrence-arbitrationmediation-negotiation-forgiveness and reconciliation. However, conflicts do not 
follow this linear path. In terms of the participants of the current research, if indeed the Holocaust might be called a conflict, their parents left the continuum in the throes of the war of extermination when they came to the United States. This was the manner in which they, with great personal losses, accomplished deterrence for themselves, therefore, the inclusion of arbitration, mediation, negotiation, are beyond the scope of this paper. However, we will briefly look at forgiveness and reconciliation, which are challenging concepts that may be different in practice than in popular conceptualization.

There may or may not be forgiveness or reconciliation for the secondgeneration. There are some misconceptions about forgiveness. Hocker and Wilmot (2014) are clear when they say "forgiveness does not dismiss or minimize an event or situation" and "forgiveness is not indifferent about justice" (p. 308). On the other hand, Hoffman (2004) writes: "The second-generation is the hinge generation in which received, transferred knowledge of events is transmuted into history, or into myth. It is also the generation in which we can think about certain questions arising from the Shoah with a sense of a living connection" (p. xv). She asks: "After such knowledge, what forgiveness?" This is a challenging question and doubtless there are many possible responses. Yet, these questions were not broached as they were outside the focus of this present study.

An excellent study on the distinctions to be made in the concept of forgiveness is Simon Wiesenthal's The Sunflower: On the Possibilities and Limits of Forgiveness (1976/1998). Wiesenthal presents a true episode from his own 
incarceration as a slave laborer in an extermination camp and asks others to respond whether or not they would have forgiven a dying Nazi SS officer who had, by his own admission to Wiesenthal, brutalized and murdered a number of Jewish people. Wiesenthal did not forgive him and in these books he eloquently discussed the different forms of forgiveness. Respondents included in these two editions did or did not forgive and stated why they made their decisions. Future research with the second-generation would benefit greatly to continue Wiesenthal's dialogue as it impacts the generations.

Tint (2009) says: "Reconciliation or "shalom" (peace and wholeness) requires, in the Jewish tradition, the perpetrator to have a deep turning within the soul (t'shuvah). This includes acknowledging the wrong committed directly to the victim, realizing what the impact has been on the victim, offering assistance to the victim, and promising to live his/her life with integrity, thereby returning integrity and peace to both sides" (p. 279). In the United States, the second-generation are separate from the European sphere of their parents, not only in geography, but in time, which are two of many challenges in the concept of potential reconciliation.

Lederach (2003) noted that the use of the term conflict resolution is not applicable to all people and many people find it suspect. In his work, he found that the concept of resolution implied to some people the "danger of co-optation" without the possibility for the change processes for the people. Lederach then adapted his approach to conflict transformation. He makes the case for this semantic and philosophical decision in that resolution implies bringing an end to 
something solvable, whereas, transformation "directs us toward change" which has a longer term vision and is more "crisis responsive" (p. 29-30). Yet, for the participants of this current research even the idea of conflict transformation falls flat. For the participants here, as stated above, there were no transformations in their parents' home countries. The parents, to save their lives, were forced to leave to emigrate to the United States. The majority of the parents did so, but most were unable to bring their family members or their physical assets.

What we are looking at then, are cases where either during or following the Holocaust some people were able to escape and transform their lives from a place of great anguish, to create a place to attend to life's necessities, such as learning a new language and new job skills, and to marry and to have children; these children being the focus of this present research. The second-generation are living testaments to the resiliency of their parents who overcame unfathomable odds and as children of these parents the second-generation are themselves manifesting resiliency. Most of the survivors of the Holocaust have died, such as, the parents of the participants in this study. This is a critical time to visit the children, the second-generation, to inform us of the reverberations of the Holocaust living on with some attendant intergenerational trauma, but overall to acknowledge incredible feats of resilience and post-traumatic growth.

Post-traumatic growth is a fundamental aspect of conflict transformation in this paper. It is distinctly different from recovery which had these parents remained in their countries of origin might have been a useful lens. The 
Holocaust survivor parents under discussion had to find ways to adapt and thrive in terms of post-traumatic growth propelling themselves and eventually their children into meaningful lives. Tedeschi and Calhoun (2004, p. 1) say:

Post-traumatic growth is the experience of positive change that occurs as a result of the struggle with highly challenging life crises. It is manifested in a variety of ways, including an increased appreciation for life in general, more meaningful interpersonal relationships, an increased sense of personal strength, changed priorities, and a richer existential and spiritual life.

Though notably Tedeschi and Calhoun redefine the words thriving and flourishing in their discussion. They view post-traumatic growth as following "a significant threat or the shattering of fundamental schemas and may at times coexist with significant psychological distress" (2004, p. 4). They also draw distinctions between resilience and post-traumatic growth. Resilience, in their terms, is the ability to go on with life after major crisis and stressors, whereas, post-traumatic growth is more in depth and farther reaching as it takes people beyond their pre-trauma selves, which as the Holocaust survivor parents were teens or young adults at the time of the Holocaust appears to be more accurate.

\section{Significance of Inquiry}

The Holocaust has not been the only incidence of lethal persecution against Jewish people; therefore, it is not surprising at all that seventy-five percent of Jewish second-generation people would be apprehensive about another 
Holocaust (Hass, 1990). What is surprising, for me, is that there are twenty-five percent of second-generation people who do not have this trepidation. Were it not for the source, one might read a suggestion that only the majority of people with a biological connection to the Holocaust would be fearful of another Event. Yet, apparently more than ten percent of non-Jews believe another Holocaust might happen. Hass asks us to consider: "When one acknowledges the Jewish people's relationship to the non-Jewish world for the past two thousand years, one's understanding of periodic, violent, anti-Semitic outbreaks produces a certain outlook and expectation" (p. 128).

The modern day presence of anti-Semitism throughout the world indicates there is a possibility that history might repeat itself. In response to the rising tide of European anti-Semitism, Gurfinkiel, a French journalist and prolific author, published an August 2013 article in Mosaic: Advancing Jewish Thought. He cites the analyst Dr. Wistrich, an authority on anti-Semitism: "Any clear-sighted and sensible Jew who has a sense of history would understand that this is the time to get out [of Europe]." Gurfinkiel (2013) continues:

For many European Jews [emphasis his], there is indeed a déjà $v u$ quality to the present situation... They know, from personal experience or from the testimony of direct and irrefutable witnesses, how things unfolded in the not too distant past, and how a seemingly normal Jewish life could be destroyed overnight. When anti-Semitic incidents or other problems accumulate, they can't help asking whether history is repeating itself. 
Given the technological advances of our world, perhaps it could be something larger and even more horrific than the Holocaust. We cannot presume to say how prescient this concern is at this time, but it is under discussion in many venues. If we can learn more about history, the Holocaust, refugees, and forced migration, perhaps an intervention may be possible. At minimum, aside from such travesties as the Trail of Tears Indian Removal Act of 1830, since no wars have occurred on United States soil since the 1861-1865 Civil War, we need to be competent in matters of post-migration challenges and work toward promoting post-traumatic growth in individuals, families, and communities.

The idea that we stop at what determines making sense for us is important, though some experiences might move us beyond a place where that can happen. Husserl [1859-1938] died before the intensity of the Holocaust, yet he would have known about the lead-up to this period since 1933, at minimum. In his terms we are all "living human beings in the life-world" of our own experiences, hence, memory. In conflict resolution and transformation we must address the life-world and memories of others with an eye to the future through comprehension of both the past and the current situation. There has been an unusual uptick in the study of memory, a memory boom, whereby more people than ever before have shared their lives in recorded memory. Over approximately the past thirty years memory has changed people's relationship with the past (Nora, 2011). Nora is the author of the famous quote "Whoever says memory, says Shoah." There is a great deal of discussion whether or not the Holocaust is directly responsible for the sudden 
increase in memory studies (Olick, et al., 2011, p. 29). Writing memoirs is cathartic for survivors of all kinds of trauma and perhaps particularly influenced by the memoirs of the survivors of the Holocaust.

\section{Chapter 2 - Memory}

Memory and identity are intertwined through our life-worlds. But this is not solely of the individual. Societies share some cognitions and beliefs about their community. These concerns of the particular society "contribute to the sense of uniqueness and social identity, are developed and disseminated in the light of significant experiences of society members" (Bar-Tal, 2003, p. 85). Memory is at once both in the individual and in the individual's social, ethnic, and family groups. Memory may also be a way we honor those we have lost.

Bellah et al. (2011) say, "A real community... is a community of memory, one that does not forget its past" (p. 229). They elaborate that memories of the past also turn us toward the future: "They carry a context of meaning that can allow us to connect our aspirations for ourselves and those closest to us with the aspirations of a larger whole and see our own efforts as being, in part, contributions to a common good [italics theirs]" (p. 229). For the common good is a part of the Jewish practice of tikkun olam, which will be discussed shortly.

The second-generation are in an untenable position as they were unable to take any action during the Holocaust (which is not to say that the survivors had many options available at the time). With the passing of the survivors, there is a 
paradigm shift. The second-generation speak "about" the Holocaust having its presence in their entire lives and Berger (1997) said: "This generation seeks to find its own way of shaping the memory and the legacy of the Holocaust" (p. 20). We need to keep their family stories in the public sphere; however, not all children of Holocaust survivors have this desire.

János Szász in the five-part film Broken Silence (2002) segment titled: "Eyes of the Holocaust," included a woman survivor who says the only people who really understood about the Holocaust were the people who perished in it. It should also be clear that the available literature here does not include all survivors as we have heard almost nothing from some survivors, such as, the Roma, homosexuals, and political prisoners. This is a loss for all of us. The German Jewish philosopher Hannah Arendt, to paraphrase, asks that the Holocaust be viewed as a crime against humanity fought out over the Jewish body rather than solely a Jewish catastrophe. Yet, it does not escape our notice that with six million dead the Holocaust was a direct assault on world Jewry.

In the public, the appetite for "memories of others" apparently finds the Hollywood and fictionalized versions of memory more appealing. Instead of the newsreels of the time which are horribly graphic we are more likely familiar with the Steven Spielberg film Schindler's List (1993) billed as a drama, biography and as history. The film has an aura of authenticity by having actual Holocaust survivors walk beside the actors in the conclusion of the film. However, though there was an actual Oskar Schindler whose famous "list" is in the Nazi archives at 
Bad Arolsen (Germany), the film was based upon the fictional novel by Thomas Keneally, Schindler's Ark (1982). The merger of true memories with fiction is a huge issue in Holocaust Studies.

Another aspect of other people's memories is in the idea that (objects or) physical places may evoke a "transferential space" where "memory and affect get transferred from one person to another" (Gross \& Hoffman, 2004, p. 35). This effect may be achieved through the presence of Holocaust Memorials including the United States Holocaust Memorial Museum (USHMM), as well as, any place cited and recorded in someone's memories. People cannot quite be in this transferential space as Bukiet (2002) writes:

The Second Generation will never know what the First Generation does in its bones, but what the Second Generation knows better than anyone else is the First Generation. Other kids' parents didn't have numbers on their arms. Other kids' parents didn't talk about massacres as easily as baseball. Other kids' parents had parents. Other kids' parents loved them, but never gazed at their offspring as miracles in the flesh. Most of us weren't born in mangers, but we might as well have been. Other kids' parents weren't considered a retroactive victory over tyranny and genocide (p. 14).

Radstone (2008) addresses memory in academic terms and calls for a trans-discipline approach to memory studies within culture studies. Of interest to her is how the study of memory transforms politics. Radstone writes eloquently upon the writings available from witnesses and survivors. She uses the common term: trauma texts. She has some tremendous insights and draws the reader's 
attention to an aspect of memory studies not readily found elsewhere. She writes: "What seems absent, then, from analyses of trauma or wound culture is that attempt to understand culture - including these versions of memory culture - as ambiguous, as struggle, as a grey area" (p. 36). The second and third-generation people she references do give us deeper insight into culture, politics, and history.

Memory is both the place and the process where we store our experiences and is comprised of historical, present and future tenses of our lives. The manner in which we make sense of it all is filtered through an individual's memory which, to recall Kraft, involves the vividness of the mind's eye and the bodily sensations arising from those memories. Oppenheimer and Hakvoort (2003) point out that Maurice Halbwachs wrote that groups and societies also have memories which we call "collective memory." They say: "A relation is assumed between collective and individual or personal memory by which individuals' memories of events may conflict with the larger society's representations of the same events" (p. 94). The differences therein may be resolved by inquiries of the people who have experienced that which we seek to know.

It follows that on the origins of memory we must first look to the family. We are largely born with the ability to have memories and, indeed, may have neonatal memories. It is exceptional that nearly all human beings have memories, excluding some with neurological disorders and certain diseases. In a way, one might think of memory as connecting all human beings to one another on a level apart from time and space. 
Tint (2003) writes that family stories "largely through oral transmission, are a central and important source of collective memories passed down through the generations. However, it is not only personal memories that are cultivated, but political and cultural ones as well" (p. 25-26). Of course, most families begin with biology, yet, there are adoptions, extended family and, through exogamy per se, the inclusion of others not biologically related. Furthermore, we must recognize and support the role of memory in all of these identities. Bellah et al. (2011) hold that people grow up in "communities of memory" which is where the hopes and fears are known by all. They elucidate there are "practices of commitment" which not only define the community but keep the community alive. These practices encompass ritual, aesthetics, and ethics.

Another researcher, Zerubavel (2011), writes that our families are the very first "thought communities" we are in. She discusses mnemonic socialization which is very important. Children, more than others, in this sense have a plethora of what Zerubavel names "mnemonic others." Surely we all have mnemonic others, the people who remind us of what we have forgotten or what we have yet to learn. A specific problem for children, in particular, is that this might preclude the ability of the individual to create their own memories. Zerubavel notes that this is a keen issue for young children as parents and others also define "what is real (as well as memorable) and what is not" (p. 221). Parents usually move to protect their youthful children from facts, events and issues they are too young to experience. Parents have different approaches to protecting their children in their 
formative years. Some parents do not discuss traumatic events with their children for obvious reasons, such as the graphicness and vileness of the Holocaust. Yet, other parents partially disclose or in some ways minimize the severity of trauma with an eye toward protecting their children. Thirdly, some parents disclose more readily to their children which might have mixed results. Some children might be too young to comprehend. In the end, whichever path is chosen children may incorporate what they know of their parents' experiences into their own identity.

\section{Memory and Conflict Resolution}

It is not uncommon in conflict resolution to come across the terms "collective memory," "cosmopolitan memory," "communities of memory," or simply, "memory," as if, inherently, we all agree upon what we mean. Therefore, drawing out, examining memory and working with it, including all of the political ramifications, is a vital element in conflict resolution. The moment we bring two or more people into relationship, we have their memories influencing the experience including conflicts, processes and outcomes. Yet, in reality, we only need one person to find memory. We might also consider that perhaps the expression of one's memories of traumatic events may lead to healing.

Levy and Sznaider (2002) take the concept of "collective memory" into a wider realm due to the global nature of the memories, in that they are no longer nation-bound or ethnic-bound indicative of one particular people. The authors call this new manifestation cosmopolitan memory. Or, in the authors' words: "a 
memory transcending ethnic and national boundaries" (p. 88). This fits the present study as we will encounter people whose origins are from different parts of Europe. The aspects they share are that of being Jewish and secondgeneration. To further elucidate, Levy and Sznaider write: "We are not studying the historical event called the Holocaust, but rather how changing representations of this event have become a central political-cultural symbol facilitating the emergence of cosmopolitan memories" (p. 88). With the memory boom, the Holocaust is the most widely studied genocide in the world.

With the previous discussion of the rupture in intergenerational memory caused by the Holocaust, communities of memory appears to be a better description of the memory processes. Certainly each individual has his or her memories, but we tend to come together with others with whom our memories have resonance. Many of the second-generation have sought one another out to form discussion and support groups. We may not be in a collective with all other people, nor particularly cosmopolitan, but find we are aligned in communities. In the community of memory, we have the clearest political expression of memory. The community of memory may be one of the strongest elements for survival and subsequent successes of post-Holocaust individuals and families.

Conflict resolution practitioners study conflict and transformation. BarTal (2003) says: "A culture of violence develops in response to the experiences of physical violence accumulated during intergroup conflicts, and is based on the subsequent evolved collective memory that preserves those experiences and their 
meanings" (p. 84). In a very limited sense, the Holocaust might be seen as intergroup conflict. The Jewish people were victims not only of the Nazis but they were victims of their neighbors, as well. Bar-Tal concludes: "This development is almost inevitable in view of the human losses that the society incurs through decades of conflict and the participation of its members in the violent acts" (p.84). Survivors of the Holocaust, and subsequently, the secondgeneration, practice post-traumatic growth as they resumed, rebuilt, and/or created lives with an exceedingly rare reaction toward being life-affirming rather than perpetuating violence or conflict of which they were the victims. They moved far beyond a violent reaction to previous circumstances of the Nazi regime.

Cairns and Roe's study (2013) of collective memory and conflict resolution points out that identity is constructed and reconstructed upon one's memories. Memories may become more or less prominent over time. Aware of our memories, we are dependent upon our interactions with others which yield meaning and purpose in our lives. Bringing to the foreground, Cairns and Roe say: "Frisch (1989) acknowledged that collective memory, as a process, involved societal and individual level processes that were interdependent in as yet imperfectly understood ways" [italics mine] (p. 13). Frisch made the case for history and identity being directly linked. We have the sense that this is happening, but it is difficult to explicate. There are so many variables in the human psyche, but memory and history contribute largely to identity. 
As conflict resolution and conflict transformation practitioners, we are missing a very large piece of the narrative if we do not study the history of the event. History is defined not only as personal history, but of ethnic, religious, regional or national identity building blocks. Though, as said, simply because one has experienced violence or different levels of persecution and intolerance which has been directed against them, not all people respond with violence. Indeed, many people strive to embrace the world and perform incredible feats. Tint (2010b) sums the field up: "Within conflict resolution practice, we are constantly moving among old wounds, present dilemmas, and future solutions." (p. 369).

Cairns and Roe (2003) write of the politics of memory, saying: "a persistent feature of more recent sociological accounts has been a stress upon the political aspects of social remembering and forgetting" (p. 14). In particular, the constraints placed upon memory through different societal structures and access to information matter and are change agents. They advise: "Writers have pointed to the manner in which social memory processes are shaped by the structure of societies and the relative status enjoyed by different social and ethnic groups" (p. 15). Varied levels of status are important. Fogu and Kansteiner (2006) note "the threshold between the individual and the collective is often crossed without any adjustments in method." This may or may not be, but it does provide fertile ground for the gleaning of some salient points and the discard of others as chaff. In other words, "collective memories" are accessible for political use and, unfortunately at times, misuse. 
A key problem is defining a collective. The memory boom appears to be dissolving borders between people. Study of the Holocaust, is making the history accessible to all through many formats such as the books and films. The collective interested in the Holocaust has expanded well beyond the Jewish community. Perhaps this global interest may provide some insulation to protect against the deniers and other charlatans who trivialize the Holocaust.

The Holocaust is a piercing era of history, and yet, others make use of holocaust terms and events. Cairns and Roe (2003) note: "The passage of time... may actually serve to increase the emotional sense of grievance and the intensity of the collective memory for those concerned" (p. 15). The Holocaust happened where those who became victims were part of the fabric of their communities. Non-Jewish neighbors turned against their Jewish neighbors. Each community, with the notable exception of a few, such as the entire nation of Denmark or Sweden, actively handed Jews over to the Nazis. In Poland, the Poles killed Jewish people without the Nazis. This compounds what happened during the Holocaust into a nearly unimaginable situation. After the Holocaust, many survivors chose not to return home and/or were unwelcome when they did try to return home. For all sorts of conflicts, these events impede closure and attempts at reconciliation. Indeed, Cairns and Roe point out that "unaknowledgement" [italics theirs] makes it "very difficult for victims even to contemplate intergroup forgiveness" (p. 175). The collective, then, must take this into account. 
Memory and the Holocaust

Memory is not easily shared with others who do not have the context. Engelking (2001) shared an excerpted interview delineating some problems of discussing memory between the generations or with anyone else for that matter. Her interviewee Marek says: "You have no common language with someone who didn't live through it. How could you talk about it? Someone living in normal conditions isn't capable of grasping it" (p. 251).

The manifestation of feeling the experience is so important. Laub (1992) writes that we come to know more of ourselves in the idea that we have to face ourselves in the process of empathy, though he does not say so in exactly these terms. Laub says:

The listener can no longer ignore the question of facing death; of facing time and its passage; of the meaning and purpose of living; of the limits of one's own omnipotence; of losing the ones that are close to us; the great question of our ultimate aloneness; our otherness from any other; our responsibility to and for our destiny; the question of loving and its limits; of parents and children; and so on (p. 72).

In the realm of memory, these aspects are true of both the person remembering and the person these memories are disclosed to, if at all. Not all memories are spoken or recorded. A hallmark of the Holocaust is that so many people, such as Marek above, simply could not speak to another of their experiences, yet, many wrote memoirs rather than speaking the words. We must 
keep in mind that this present study regards the memories of the children of Holocaust survivors, thus, the children did not directly experience the Holocaust.

The parents of the second-generation were refugees or in many senses forced migrants. For some, the burden of memory has been more difficult to overcome than for others. We might think of it in Viktor Frankl's terms where he, as both a Holocaust survivor and a noted psychiatrist, said that the ones who survived the Holocaust had hope, whereas those who perished or were disabled by the experience had lost their sense of hope. Hope was an attribute he recognized in a number of survivors, including himself. We might think of this as a delineation between those who were victimized not only in body, but in spirit and mind as well, and those who were hopeful for life after the Holocaust.

A very compelling survivor's voice is the "Philosopher of Auschwitz," Jean Améry. He asked: "Who owns a human being" which was elegantly incorporated into an essay by Kertész (2001) as "Who Owns Auschwitz." Auschwitz, first implemented to incarcerate Polish political prisoners, has become a catch-all word to include all of the Holocaust.

Holocaust survivors will have to face the facts: as they grow weaker with age, Auschwitz is slipping out of their hands. But to whom will it belong? Obviously, to the next generation, and to the one after that - as long as they continue to lay claim to it, of course (p. 267). 
Yet, is this possible? Is the Holocaust to be held in an irreducible and permanent modality?

Kertész (2001) warns us: "More and more often, the Holocaust is stolen from its guardians and made into cheap consumer goods" (p. 268). Vehemently he declares: "Or else it is institutionalized, and around it is built a moral-political ritual, complete with a new and often phony language." And, finally, "Certain words come to be compelled by public discourse, and almost automatically set off the Holocaust-reflex in the listener or the reader" (p. 268). This so-called reflex is very important to the present study. This isn't a question of the second-generation owning the Holocaust, but care needs to be taken that the Holocaust experiences are not made into disposable "cheap consumer goods."

\section{Memory and the Second-Generation}

Helen Epstein, second-generation survivor of two Holocaust survivor parents, writes powerfully in the beginning of her work Children of the Holocaust: Conversations With Sons and Daughters of Survivors (1979) about being second-generation:

For years it lay in an iron box buried so deep inside me that I was never sure just what it was. I knew I carried slippery, combustible things more secret than sex and more dangerous than any shadow or ghost. Ghosts had shape and name. What lay inside my iron box had none. Whatever lived inside me was so potent that words crumbled before they could describe" (p. 9) 
Berger (1997) says: "Works of the second-generation witnesses are attempts to unlock [Epstein's] box, share its contents, and, in the process, contribute toward the achievement of tikkun olam, something for the "good of the world" (p. 18). And, yet, what Epstein discovers is not the same as all discoveries. At the time she was writing, she was speaking of the sons and daughters who had been born directly in the aftermath of the Holocaust. Their parents were in the arduous place of being deeply in grieving processes, while reestablishing themselves in a new homeland, learning a new language, with all the traumas still upon them as they struggled to regain living their lives.

In the complexities for the second-generation, it is not surprising that a number of studies which have been done researched the psychiatric issues and correlates, yet, have contradictory findings (Gangi et al., 2009; Kellerman, 2001; Nadler et al., 1985; Tauber, 2003). Nadler, et al. (1985) studied thirty-eight males and females in their twenties in Israel. Nineteen of the participants were the children of Holocaust survivors and the other nineteen were a control group as children of people who had lived in English Mandate Palestine (1920-1948) during the Holocaust. (The nation of Israel was founded there in 1948.) Content analysis was applied to the results of structured interviews with each of the participants. The results were that second-generation survivors were less likely to externalize aggression than were the control group. A key finding was: "The child growing up in the home of holocaust survivors seems to be burdened by 
feelings of indebtedness and responsibility toward the parents and by a need to fulfill the parents' expectations of self" (p. 368).

But, this is not exhaustive. Kellermann (2001) acknowledges after his significant review of available studies that research into the second-generation is not without controversy. Where some therapists believe there must be trauma in the children of survivors while: "In fact, many have lately suggested that the "legacy" of the Holocaust has influenced the personal lives of offspring in a positive manner by making it more meaningful and by increasing their compassion for human suffering" (p. 36-37).

In another Israeli study of Holocaust survivors, second-generation survivor and therapist Tauber gave her work a fetching title: "We're Listening, But Can We Hear? Psychotherapy with Holocaust Survivors and the secondgeneration in Israel, Under (Threat of) Conditions of Armed Conflict" (2003). In particular she notes how a current threat or act of violence can negate some of the healing we may think has occurred: "Under certain conditions, such as armed conflict, even well intentioned listening does not guarantee that this population is actually heard" (p. 18).

If indeed, we are not listening to survivors and second-generation, what becomes of their memories? Do we merely listen when it suits us? Or, perhaps only when we feel safe? Or, perhaps when we have transient moments of stepping outside of ourselves to give ourselves over to dynamic and empathetic 
listening? Do we really think we already know about the Holocaust and the second-generation? In conflict resolution there is a demand that we be active listeners at all times. We do not have the ersatz luxury of selective listening. Central to Tauber's thought is the concept of "conspiracy of silence" which she ascribes to almost everyone, including survivors and second-generation.

A more recent Italian quantitative study of Holocaust survivors and the second-generation (HSO) by Gangi et al. (2009) says: "Although the HSO displayed no serious psychological consequences, they had higher anxiety levels than controls, low self-esteem, inhibition of aggression, and relational ambivalence" (p. 687). Other researchers have different findings. Scharf and Mayseless write "[In Israel] qualitative analyses were based on two interviews: The Adult Attachment Interview (AAI; George, Kaplan, \& Main, 1985) was conducted with the parents and the adolescents separately, and the Parenting Representations Interview-Adolescence (PRI-A) was administered to the parents" (Scharf \& Mayseless, 2010, p. 1542). Their results: "Second-generation Holocaust survivors might not show direct symptoms of post-traumatic stress disorder or attachment disorganization, but are at risk for developing high levels of psychological distress" (p. 1539). Possibly there has been too much emphasis on the concept of pathology trauma in the spectrum of being second-generation in the available literature. The children of Holocaust survivors are also a source of love and hope for the survivors, and indeed, these factors make it clear that the second-generation are life affirming for the survivors (Nadler et al., 1985). 
There is perhaps no method of removing from one's consciousness the memories we retain, even though we may have forgotten some through trauma, willfulness or another experience. Yet, by these very attributes, memory might also be called forth. It is critically important that neither survivors nor their children, the second-generation, be pegged into pathology without due consideration. They did have to overcome great traumas, but also exhibited great personal strength and, as Engelking remarks, had a tremendous resilience and self-renewal despite having had such experiences.

A "Second-Generation Syndrome" might be a pathology of neuroses and a sense of damage. This might be based on the survivor parents as Danieli posits four types: victim families; fighter families; numb families; and "those who made it." But, what if not exactly? To Berger (1997): "This memory [of the secondgeneration] expresses itself behaviorally in both particularist and universalist manner, seeking to achieve a tikkun [italics his] of the self and a mending of the world" (p. 184). For Berger, looking at the second-generation is not in looking at their pathology, but in examining their complexity. In his summation of Deborah E. Lipstadt's (1979) work titled "We Are Not Job's Children," the secondgeneration might have difficulty with the following issues:

(1) "Separation from frequently overprotective parents"

(2) "The "phenomenon of the impossible comparison," that is, the feeling that their own problems and lives have less meaning than their parents'" 
(3) "A need to be "superachievers" and thereby somehow undo the trauma of the Shoah [Holocaust]"

(4) "A feeling of loss in terms of a diminished family circle"

(5) "Seeking to find a personal mode to express their thoughts about the Holocaust and to "insure continuity with their family's past"" (Berger, 1997, p. 14).

Berger added his own sixth point to this list noting that some of the secondgeneration sometimes need to "achieve a mimesis" of their parents Holocaust experiences. An example he cites is Art Spiegelman, author and illustrator of the Maus series (1980-1991), as a creative interpretation of his father's Holocaust experiences. Overall, Berger notes the need for many of the second-generation to "make sense" of the [senselessness of the] Holocaust (p. 14-15).

\section{Summary of the Literature}

Memory is a phenomenon of essential exploration for many reasons including the celebration of life, the narrative of our lives, the resolution of previous injuries, if possible, and if not, the sheer power of the acknowledgement of suffering and loss. Booth (2006) provocatively says of memory:

The act of bearing witness is also a gesture of defiance and resistance against the flow of time which distances us from what went before, against an absorption in the present, and against the desire to forget or conceal. It is an act of resistance related to an absence, a silence, and therefore to a certain kind of vulnerability: that what is absent will be forever lost. (p. 75). 
The memory of second-generation Holocaust survivors is vitally important as we have seen in the available literature. Through our identities we interact more and more globally with one another. We are dependent upon the secondgeneration to keep their memories and their parent's memories in the public sphere; however, not all children of Holocaust survivors have this desire. Norman Finkelstein (2000), son of survivors, fierce critic of Israel, educator and prolific author is vehemently against what he calls "The Holocaust Industry" (p. 120). Finkelstein's frustration was clear in the film Defamation (2009). He concluded the interview by making a Nazi gesture. Though he does not "fit," in this provoking instance, the community of memory includes him. Therein is a caveat against assumptions, there is not just one mode of being a second-generation survivor. The most pressing thoughts in the literature are the ideas of "other kids' parents," liminality and the unaknowledgement which continues to this day. The use of the term liminality, or threshold, is in the sense of Carl Rogers as from being in a long tunnel. 


\section{Chapter 3 - Methodological Process}

This chapter explains the methodological processes used for this study. A discussion of phenomenology is followed by the data collection processes utilized and, finally, the participants of the study are introduced.

A phenomenological approach was chosen for this inquiry. "Lived experience is the starting point and the end point of phenomenological research. The aim of phenomenology is to transform lived experience into a textual expression of its essence..." (van Manen, 1990, p. 36). Creswell (2013) has also written about phenomenological research design where the focus is "understanding the essence of the experience" (p. 104). Phenomenological approaches elicit stories from participants in order to discover the meaning of experience to the participant as revealed in their account. Creswell said this is different than a strictly narrative research design because in phenomenology we seek to find "the common meaning for several individuals of their lived experiences..." (p. 79). The use of phenomenology in conflict resolution is appropriate as it is uniquely designed to grant insight into personal histories which might not otherwise be revealed.

The Holocaust is the most studied genocide in history. There have been many first person accounts, both fictional and authentic, with which we may be familiar, possibly conditioning our expectations of new stories. These biases may preclude us from seeing the unexpected. My personal strategy to manage 
potential biases and assumptions was to enter a null state where anything was possible. In other words, I let go of any preconceptions concerning where this research might go. There was no way I could know whether or not this research would elicit anything in particular.

The decision to utilize a transcendental phenomenological approach seemed to be the most appropriate for this study. There is no editorial interpretation, but a direct conveying of each of the participants' own words. In phenomenology we look at different experiences in life as phenomena. In transcendental phenomenological reduction everything is perceived freshly "as if for the first time" (Moustakas, 1994, p. 34). Here the participant is an "open self:"

The phenomenon is perceived and described in its totality, in a fresh and open way. A complete description is given of its essential constituents, variations of perceptions, thoughts, feelings, sounds, colors, and shapes. Ultimately, through the Transcendental-Phenomenological Reduction we derive a textural description of the meanings and essences of the phenomenon, the constituents that comprise the experience in consciousness, from the vantage point of an open self.

In this manner we may see people's ways of being through the narratives given to us in trust, that we might understand the depth and range of their experiences. The meanings come to us through their descriptions and perhaps are most readily understood when they touch some part of our own experiences. The epoché process is called "bracketing." This is the technique whereby we try to 
move the phenomenon into a realm unhampered from everything else we might know or think we know (Moustakas, 1994). Van Manen (1990) cautions:

The problem of phenomenological inquiry is not always that we know too little about the phenomenon we wish to investigate, but that we know too much. Or, more accurately, the problem is that our "common sense" pre-understandings, our suppositions, assumptions, and the existing bodies of scientific knowledge, predispose us to interpret the nature of the phenomenon before we have even come to grips with the significance of the phenomenological question (p. 46-47).

The stories elicited involved remembering. When we remember we are transported back to events in our past. However our recall is filtered through experience, the prompt for the remembering, and our subsequent interpretations. Therefore in a real sense our stories are reconstructions not reproductions. Nevertheless, something of a truth endures (Ricouer, 2004). This truth emerges from the detailed descriptions and convergences of the different participants' accounts. For this study the participants' stories were recorded and transcribed.

...a descriptive analysis attempts to understand the meaning of the description based solely upon what is presented in the data. It does not try to resolve ambiguities unless there is direct evidence for the resolution in the description itself.... The descriptive researcher obviously sees the same ambiguities that an interpretive analyst would see but is not motivated to clarify them by bringing in nongiven or speculative factors (Giorgi, 2009, p. 127). 
For this research the eventual grouping categories spontaneously emerged from the participants' stories. There were not predefined themes nor perhaps even expectations given that I had no prior conception of the content of the participants' stories. Each participant had stories or concerns revolving around the media, education, tenacity, resilience and the tenuousness and fragility of life. Stories were then grouped together as common themes were touched upon.

\section{Data Collection Processes}

A phenomenological interview protocol was used to structure interviews with second-generation participants (see Appendix A). Eight interview questions were developed to elicit how the lives of the second-generation were shaped by their parents' experience of the Holocaust and their coping in the aftermath. The specific goal was to examine intergenerational trauma and resilience. The questions broadly cover four aspects of the participants' lives. The first question was a simple query: "Please describe your family." The second and third questions were related as they ask the age of the interviewee when they first learned about the Holocaust and from whom they first learned about the Holocaust. The next four questions are all directed toward understanding the position of the second-generation participant in their world. These questions cover their reactions to the use and misuse of the word Holocaust, difficult aspects of being second-generation, whether or not (and when) their second-generation status is disclosed to others, and then, what do the interviewees wish that others 
knew about them. The final question was "How have your parents' memories shaped who you are?"

The next step was to identify potential participants. I distributed business cards to anyone who showed an interest in the research to share with potential participants. Additionally, a second-generation group was identified through the auspices of the Oregon Holocaust Resource Center. An email query was made to members of this group to ascertain whether any might be prospective participants.

Potential participants either called or emailed me. Little information was exchanged at this point other than to affirm that the potential participant was second-generation. If so, an interview date was set. "Interviewee fatigue," whereby a second-generation person may have been overly questioned in the past, was an unfounded concern as twenty potential participants made contact. Ten of these were interviewed for the study. The other ten were not included for a variety of reasons including not meeting the research criteria or not being emotionally prepared. For example, one woman wept during the initial phone call and said that "the Holocaust had ruined her life." Her distress was so great she was nearly inarticulate. Ultimately she made the decision not to participate.

The interviews took place at the business or residence of the participant at the participant's invitation. Two of the ten chose to be interviewed in their business settings while the other eight chose to be interviewed in their homes. Seven women and three men were interviewed. Each interview was filmed. The 
participant read the IRB approved consent form for video (Appendix B), except for one woman who signed both the written (Appendix C) and the video consent forms. The written consent form was only used for one participant. She had initially solely wanted to write her responses, but when the time came she also wanted to have the video interview. Each participant signed the consent form prior to the start of the interview. The participant was given a copy of the consent form and a copy of the questions to read before the interview commenced.

The questions were posed one-by-one by the researcher who remained off camera. One participant read each question aloud and then answered it. As she appeared to be most comfortable in this manner, the interviewer did not interject. Two participants wept during the interviews and one additional participant fought tears at times. However, all wanted to continue when asked if they wanted to end the interview. At the conclusion, all participants appeared satisfied to have shared their experiences.

Several of the participants wanted copies of the video of their own interview. These were mailed to them. The Institutional Review Board had specified that the videos were the property of the participant, and that the researcher's original was to be destroyed following transcription. This was done. Pseudonyms are being utilized to protect the privacy of the participant. 
Introducing the Participants

The participants are American-born Jewish people from the Portland, Oregon metro area. Table 1 displays demographic information including the age of their parents, the parents' date of marriage, and the age of the participants. This information is in some cases incomplete. If the participant mentioned not knowing a fact the term $\mathrm{u} / \mathrm{k}$ [unknown] was used. For example, Joseph did not know what year his parents married. If there was no direct reference to these points, the term $\mathrm{u} / \mathrm{d}$ [undisclosed] was used. For example, Rebecca did not disclose what years her mother and father were born. Otherwise, all of the information in the table was offered by the participants in their narratives.

In the column, HS [Holocaust Survivor], parents' status was recorded as Y for yes, which meant they had been in one or more of the labor, concentration, or extermination camps. An $\mathrm{R}$ refers to parents who fled the Nazi regime as refugees, eventually making their way to the United States. Finally, N for no, represents that the parent was not in Europe during the Holocaust because he or she was an American citizen living in the United States. 
Table I - Demographics of the Participants

\begin{tabular}{|c|c|c|c|c|c|c|c|c|c|c|}
\hline Participant & DOB & Place & $\begin{array}{l}\text { Mother } \\
\text { DOB }\end{array}$ & $\begin{array}{l}\text { Mother's } \\
\text { Birthplace }\end{array}$ & HS & $\begin{array}{c}\text { Father } \\
\text { DOB }\end{array}$ & $\begin{array}{l}\text { Father's } \\
\text { Birthplace }\end{array}$ & HS & $\begin{array}{c}\text { Year } \\
\text { Married }\end{array}$ & Siblings \\
\hline Adele & 1962 & USA & 1922 & Germany & $\mathrm{R}$ & 1913 & USA & $\mathrm{N}$ & 1954 & One \\
\hline Ben & 1951 & USA & 1923 & Poland & $\mathrm{Y}$ & 1918 & Poland & $\mathrm{R}$ & 1948 & One \\
\hline David & 1957 & USA & 1930 & Germany & $\mathrm{R}$ & 1927 & Poland & $\mathrm{Y}$ & $\mathrm{u} / \mathrm{d}$ & No \\
\hline Gloria & 1950 & USA & 1923 & Romania & $\mathrm{Y}$ & 1909 & Czechoslovakia & $\mathrm{Y}$ & 1946 & Three \\
\hline Joseph & 1953 & USA & 1916 & Austria & $\mathrm{R}$ & 1910 & Austria & $\mathrm{R}$ & $\mathrm{u} / \mathrm{k}$ & Three \\
\hline Karen & 1954 & USA & 1923 & Romania & $\mathrm{Y}$ & 1909 & Czechoslovakia & $\mathrm{Y}$ & 1946 & Three \\
\hline Marilyn & 1955 & USA & 1923 & Romania & $\mathrm{Y}$ & 1909 & Czechoslovakia & $\mathrm{Y}$ & 1946 & Three \\
\hline Nadine & 1952 & USA & 1921 & Poland & $\mathrm{R}$ & 1921 & Poland & $\mathrm{R}$ & 1945 & One \\
\hline Rebecca & $\mathrm{u} / \mathrm{d}$ & USA & $\mathrm{u} / \mathrm{d}$ & USA & $\mathrm{N}$ & $\mathrm{u} / \mathrm{d}$ & Czechoslovakia & $\mathrm{Y}$ & 1955 & No \\
\hline Sarah & 1949 & USA & 1924 & USA & $\mathrm{N}$ & 1925 & Germany & $\mathrm{Y}$ & 1947 & One \\
\hline \multicolumn{4}{|c|}{ HS = Holocaust Survivor } & \multicolumn{3}{|c|}{$\mathrm{u} / \mathrm{d}=$ Undisclosed } & & & & \\
\hline$Y=Y e s$ & $=\mathrm{Nc}$ & $\mathrm{R}=\mathrm{Re}$ & fugee & $\mathrm{u} / \mathrm{k}=\mathrm{Un}$ & & & & & & \\
\hline
\end{tabular}


Of the ten sets of twenty parents, ten were survivors of concentration, labor and extermination camps. Seven parents were refugees. Three parents were already American citizens who married either a refugee or a survivor of the camps. The nations which are represented by this selection (in alphabetical order) are: Austria, Czechoslovakia, Germany, Poland, Romania and the United States. There were no reported divorces nor step-family relationships discovered among the second-generations' parents. Three of the interviewees share the same parents as siblings. I was not aware of this fact until the conclusion of the interviews. There is a fourth daughter of that family, but she did not make contact.

According to the U.S. Department of Health, Education and Welfare in the United States in the 1950's, the average age of women at the time of marriage was roughly twenty years of age. For men, it was slightly under twenty-three years of age. Wed and unwed mothers were predominantly eighteen to twenty-two years of age. In this current research, we find that the mothers ranged in age from twenty-seven to thirty-nine years of age, with the average age at the time of the participant's birth nearly midway between thirty-one and thirty-two years of age. Father's ranged in age from thirty to forty-nine with their average age of nearly forty years of age at the time of the participant's birth.

The family is the fundamental building block of all societies. A proverb attributed to the Orthodox Jewish early Zionist Aaron David Gordon (1856-1922) is: "Without family life no nation can be made." Born in Russia he had endured the Russian pogroms against the Jews and made Aliyah to Ottoman Palestine in 
1904. Making Aliyah is considered "the act of going up" in the Jews return to Jerusalem. However, it was his wife, Feigel Tartakov, who convinced him to emigrate to Ottoman Palestine rather than to the United States as he had first thought. She followed him a year later. His first consideration of the United States is important in view of the families in this present study. The United States has long been viewed as a potential haven for Jewish people. Gordon held some controversial views on the suffering of the Jews in Diaspora (or the scattered population of the Jewish people throughout the nations) which he believed could be ameliorated by a return to agricultural labor in the Land of Israel.

The Holocaust rent Jewish families apart and spared no one. Even if an individual survived, it was most likely without their family. For the survivors here who came to the United States and created new families, they did so having known the depths of despair and loss. As the Holocaust was perpetrated against all Jewish people, regardless of nation, in some senses all Jewish people are second- or third-generation. The murder of millions and the destruction of so many Jewish families is irreparable, though post-Holocaust the Jewish people have survived overall and created meaningful lives in what has been a hostile world. A world which continues to be plagued by anti-Semitism and the threat of future assaults. 
Chapter 4 - Findings

Eight questions were asked of each of the ten participants to answer the research question: How have the second-generations' lives been impacted by the Holocaust? These open-ended questions elicited full, rich stories from each participant. Some of their familial hardships brought forth tears from a couple of participants and tearfulness from a third. Despite the fact that the family histories revealed extreme trauma, the second-generation participants in this study have all created meaningful lives for themselves and their children.

The eight questions brought forth nine specific themes which are addressed separately: disclosure, identity, loss, positive impact, negative impact, media, faith, education, and what others should know. Some of these themes may appear to be similar but they are distinctly separate. For example, "education" about the Holocaust is important in a factual sense. People need to know history. "What others should know," a separate theme, points more to social intelligence of the general population, while also a query into what the participants of this study view as important for others to know in the present day.

\section{His Girlfriend's Phone Number}

The first theme under discussion is disclosure, specifically from the survivor parents to their children. Disclosure is the act of making known the otherwise unknown. Research varies on the importance and/or methods of disclosure in parental revelations of their personal histories to their children, and "parental communication style, in particular, has been identified as a crucial 
determinant in the adaptation of families beset by catastrophe" (Sorscher \& Cohen, 1997, 493). Contrary to the "crucial" findings in that research, the Holocaust survivor parents of the second-generation here had unique approaches to if, when, and how they disclosed their personal histories to their children. In each life story, it was discerned that the second-generation have adapted.

Rebecca had a very gentle introduction to her father's survivor experiences. Rebecca's mother, she said, was an American and was very sensitive, in tune, and empathetic toward her husband.

Rebecca: I think early on they were cautious about how much they wanted to share with me. And as I said [the Holocaust] first came up with my identification of my dad's number [she traced her fingers up and down her left arm] and asking him: "What's that number on your arm?" And that's when it first occurred. And, my father initially told me: "Uh, it's an old girlfriend's phone number." And, I was very upset because, I thought: "Well, wait a minute. An old girlfriend's phone number? And, I said: "Well, wait a minute, what about mom's number?" And, he said, "Oh, mom's number I'd never forget. I don't need to have that on my arm." So, it was a very cute exchange and I think, in time, my father recognized that I had great interest in the subject and would bring it up and so little by little he would begin to talk.

Rebecca's father was not the only tattooed parent but he approached the subject differently than other parents did. One mother obscured the tattoo as best she could. 
Marilyn: Well, I can't remember exactly [when I found out about the Holocaust]. But one of my earliest memories, somehow I knew. They never told us, but I knew because mom had a number on her arm that she would always conceal with this skin colored lipstick. She used to put it on [her arm to cover the tattoo] and I was just a kid wanting to have fun growing up and I didn't ask what it was.

David's father, also tattooed, answered all of his questions and encouraged David at age seven to read the books at the library. David's father solely referred to himself as a "concentration camp survivor;" he never used the word Holocaust. David's mother, a refugee who refused to speak her native German after the war, said nothing about the Holocaust to David. David is proud of his relationship with his father:

David: Yes, my father would always tell me about people he saw shot and people he saw hanged. He was very open to me and I felt it was a great honor that he was telling me these stories, especially because I was so young and since he wouldn't tell them to anybody else. So, when I walked into first grade and people ask what did your Dad do during the war, I already knew that he was a concentration camp survivor and I already had stories to tell. I was very unusual; there was nobody else there who had a father who was in camps, especially eight of them, and, like I said, the two ghettos. And they didn't have a father who told them so much and so graphically at such a young age.

Ben was approximately seven or eight years old when his survivor mother became a United States citizen. There were not many Jews in his city, but the 
local newspaper carried an account of her as a Holocaust survivor achieving citizenship, which prompted her disclosure to his family. However, his mother did not speak English "all that well" to which he attributed limited discussion between his mother and her children regarding her experiences.

Each second-generation participant learned of the Holocaust with a different level of parental disclosure. The other participant responses ranged from Nadine, who said, "I don't remember not knowing" to the memories of Joseph, Karen, Gloria, and Sarah who essentially put the clues together and figured it out for themselves. (Adele did not directly answer the question.) What is unknown may be hinted at or in some manner alluded to. Parental disclosure varied family to family. Notably, all of the participants indicated that they have studied the Holocaust, particularly as adults, beyond the family sphere, which has been extremely important to their individual development.

\section{"Hi, I'm Karen, I'm Second-Generation"}

The second theme of this study is identity. The formation of identity includes both self-concept and the idea of the persona or how one presents to others. When a person is the child of a Holocaust survivor obviously they are called second-generation which may or may not be the first lens of identity the person holds of themselves, and yet, as they were born in the aftermath of the Holocaust, it is present whether articulated or not. And, in some ways, though it has always been there, it is an identity one grows into as an adult. Earlier 
researchers, such as Helen Epstein (1979), found a preponderance of pathology which is residual as the majority of studies indicate either there are or are not certain levels of pathology. Seemingly one cannot escape the appellation of pathology as a secondary label of being second-generation. Pathology, in medical terms, is often defined as a deviation from a healthy state which is not indicative of the participants of this study. The second-generation choose when and how to disclose their family status to others.

As a daughter of a Holocaust survivor, Karen rejected the identity of second-generation as pathological. While she does see second-generation as an identity, it is private and not in need of support from others.

Karen: No, it's not: "Hi, I'm Karen, I'm second-generation." No, that's personal family history and, in that sense, you don't necessarily meet people and start talking about that right away. I'm careful because it's, it's a sensitive, sad issue and I think it just depends on the situation, but it's not automatic like it's the first thing that comes up.

Many second-generation people do not readily disclose their proximity to the Holocaust to others. In many ways not disclosing is considered to be keeping good boundaries, but in other ways it is challenging.

Adele: [Being second-generation] is not something I'm ashamed of obviously. So, it's, you know, more of a people, you know, on a need to know basis. For some people it resonates more than others. And, some people are genuinely interested in knowing 
about people's family histories; you know, their own and everybody else's.

Marilyn is actively aware of the social connections between survivors, but also seems to put her own needs second to those of her deceased parents. Yet, once again we see the different boundaries the interviewees have.

Marilyn: I don't tell [others] about me, I would tell them about my parents. Especially if they have ancestors or relatives [who] are from Europe during the days of the war. [Be]cause if my mom were here she would want to know where were your parents from or where were your relatives from. [Survivors] always look for each other.

Rebecca is the most immediately forthright of the interviewees in disclosing her status as a second-generation person. She speaks of pride and that she has done a lot of studying on the Holocaust, as has David and the others.

Rebecca: I'm not ashamed of [being second-generation]. And, in many ways, I'm proud of it. When I think of what my father survived, it's remarkable. I've travelled to Theresienstadt. I've travelled to Auschwitz. I've read a lot on the subject. I'm intrigued by the subject. I studied it myself in college. And to a lesser degree, in law school. I have taken the subject very seriously. I'm proud of the fact that my father survived it, that he was at Auschwitz for two and a half years. He had great integrity and he conducted himself with good ethics. He was a good man and taught me a lot of important qualities from his experience. So, I'm not ashamed to share it and I'm open about it. 
Joseph is ambitiously working toward educating others about a specific Holocaust Survivor, Alter Weiner. Joseph feels his own experience has a lesser degree of connection to the Holocaust because his parents were refugees rather than among those who were "over there." In discussions with a wide range of people, there are distinctions made between refugees and camp survivors. It can be quite difficult for the offspring of people who were able to flee. They feel that, in a sense, they were not really "there." But they were also victims of the Holocaust, losing family, possessions, status and more. Nevertheless, some feel hesitant to claim the status of second-generation.

Joseph: Yes, when I get into discussions specifically about the movie [he has a feature film in the works based on the life story of Holocaust survivor Alter Wiener] and people want to know why am I so passionate about this and then I certainly would reveal that my parents were refugees. In normal conversations, no. You know people want to know where everyone is from. Well, my parents were Viennese. You know, I don't really go into the Holocaust aspect of it.

Neither Ben nor David readily disclose that they are second-generation, nor does Nadine, who said "it's part of a continuing conversation, not when you meet someone at a party." While Gloria and Sarah each spoke of reticence in disclosure, they also said that being second-generation includes some "amazing experiences" or that others are "amazed" when they find out. In these words we find the sheer strength, tenacity, and resilience, not only of the survivor parents, but of the second-generation, with their appreciation to have come from such dire 
circumstances and successfully assimilated into the broader American culture while, as will be discussed, maintaining their Jewish identities.

\section{What We Lost: Family and Mementos}

In the interviews, loss is the third prominent theme which included the many losses the participants and their families suffered: loss of family members, loss of status, parents' loss of livelihoods and loss of possessions. In discussing loss, how can we not think of Kübler-Ross and the five stages of grief? In her later years she said the stages are non-linear, can be co-occurring and are not applicable only to death. Any rupture involving loss might elicit these stages: denial, anger, bargaining, depression, and acceptance of grief. Elucidating these stages of grief are meant solely as touchstones for thinking about loss. It is far beyond the scope of this paper to delve into the enormity of loss each of the participants has experienced, yet, the overview this study provides, gives us some insight into the different kinds of loss, plus, the cumulative outcome..

In his interview, David quickly stated: "Right now, I'm the whole family, but I had a father and a mother and no other children." He continued: "I've never been married or had kids, so the whole family is now me since my parents are dead." He pointed out that his father had come from a very large family of four sisters, three brothers, both parents and extended kin. David's father was the only one to survive. David's father was taken away from his Polish town in 1939 and he spent five and a half years in two ghettos and in eight camps, including Bergen-Belsen [established in 1940, a concentration camp in Germany] and 
Auschwitz [established in 1940, a concentration, labor and extermination camp in Poland], as well as Buna and five additional lesser known camps. Following liberation, David's father spent four further years in a displaced person's camp while he waited for entry to the United States. David's mother was a child refugee from Germany to Shanghai. She was in the Shanghai Ghetto [the Restricted Sector for Stateless Refugees for approximately 23,000 Jewish people] for a total of seven years from 1940 forward during the war and waiting to emigrate to the United States after the war.

The only interviewee to use the word "luck" or "lucky" in a concentration or death camp was Ben. In discussion of the Holocaust with Jewish people, the use of these words often elicits sadness or anger or both. While some people might view these words in solely positive terms, many who have experienced the Holocaust, either directly as survivors or through witnessing memory as secondgeneration, do not. The idea of "luck" may undermine the sheer tenacity and risk taking that survivors of the Holocaust utilized. However Ben's use of the word "lucky" indicates that it is acceptable and appropriate at times, for some people.

Ben's narrative went on to explain part of his mother's "luck." She survived one selection due to her mother pleading for her life to a Nazi guard when they were in the lines for selection. Some to the right, some to the left. Directly following this pleading, Ben's grandmother, young aunt and young uncle were all gassed upon arrival at Auschwitz. By the end of the Holocaust, Ben's mother was one of only thirteen Jewish people from her town to survive. 
Markedly, some of the families discussed here had experienced deep losses before the Holocaust or from circumstances related to the war. Karen (with her siblings Gloria and Marilyn) had lost a grandparent in World War I which deepens the loss the family endured during the Holocaust. The later loss and betrayal of the family was acute, given that in World War I Karen's grandfather was in the infantry defending their country (the same country which would later renounce them all), but had "disappeared," whether he was killed in action or later died as a Russian prisoner of war; she did not know.

Karen: My dad basically grew up in an orphanage. [Then he returned to help run his mother's store.] In 1938, of course, Kristallnacht [9-10 November 1938, Kristallnacht, the "Night of Broken Glass," a violent pogrom against the Jews throughout Germany (and parts of Austria); that night many Jews were killed and 30,000 Jews were deported to concentration camps]. Suddenly these Nazis show up at the door, arrest him and he's taken to Dachau.

The memory of the loss of a child's innocence is reflected in all of the family narratives. Though Sarah's family attempted to find safe haven in Holland, it was not to be. Sarah's grandmother is thought to have been killed in one of the concentration camps. Her grandfather was shot in front of his sons' eyes. Both her sixteen-year old father and twelve-year-old uncle survived the camps. Joseph's parents each escaped from Vienna in 1939, as did all of their families, with just "the shirts on their backs." Joseph's paternal family escaped through Italy. His maternal family escaped through England. 
There is a wide socioeconomic gap between the interviewees. If we look at Joseph's family, all of whom survived, and David's family, the most who did not survive, there are economic aspects of importance. When David's father arrived in the United States after a long, four year wait in a displaced person camp following liberation, he worked shoveling manure for a dairy for two years. Joseph's father, on the other hand, was a physician in Vienna, joined the United States Armed Forces and then was able to become the Director of Medicine at a private hospital in New York.

As apparent, in all senses, great losses affected all Jewish families at all socioeconomic levels. For a time, early in the war, assets could be traded for one's life. Adele's maternal grandfather, an extremely wealthy man, was taken to Buchenwald [established in 1937, a concentration camp in Germany]. He was subsequently released from Buchenwald on the condition that he sign over all of his assets to the Nazis. He did so. He was permitted to take his family and some possessions with him, but they had to leave. So, Adele's teenaged mother and her family were able to escape Germany. Growing up in the United States, Adele's family "scraped by" in a very small house packed with the remnants of a formerly very prosperous life. A lithograph Adele had framed depicts an enormous flour mill with a railway dedicated to it which was one of her grandfather's holdings. Adele spoke of intentionally keeping every item her grandparents and mother were able to bring to the United States. Subsequent post-war attempts at restitution proved impossible as the lands and primary mill her family had owned 
had become part of Poland. The Polish were not held legally responsible for the Nazi's coercions, confiscations and plundering.

Buchenwald, where Adele's grandfather had been taken, had been opened less than one year before it was expanded. Adele's grandfather was not the only person to be incarcerated and then freed.

Gloria: My father had escaped Dachau a couple of times at the very beginning of the war... The Nazis hadn't figured out exactly what they were going to do with the people that they were rounding up. So you could buy people out of camps if you could prove that you were going to leave the country and so that is what happened with him. He eventually ended up in Sweden on a farm learning how to be a farmer so he could go to Palestine.

The memory of the need for families to be together is poignantly told by Rebecca as her father joined his mother, Rebecca's grandmother, to the East. The East, of course, was a euphemism for Auschwitz. The decision to implement the "liquidation" of the Jews, while clear to the Nazi hierarchy, was not so clear to the Jews. According to the testimony of Otto Ohlendorf (1907-1951), head of German Intelligence, in 1941, Heinrich Himmler (1900-1945) addressed the Einsatzkommandos [origins in the Nazi Einsatzgruppen, 1938] at Nikolayev with the orders which had been handed down from the Führer to "liquidate" the Jews while bearing no individual personal responsibility (Dawidowicz, 1975, p. 129). Rebecca's family did not know this; she said: 
Rebecca: [My grandfather] died, in Theresienstadt, of pneumonia. And then [my father] learned his mother was being transported East, but he didn't know where that was. He volunteered for the transport. It was October 26, 1942, he went on a transport from Theresienstadt to Auschwitz, or what was called, Oświęcim, in Poland. And, when they arrived at the camp, his mother went in one direction and he went in the other direction and that was the last he saw her.

Adele's mother had two older brothers who escaped the Holocaust by being in England, one at school and one working, and did nothing to assist Adele's mother or grandparents as they went through the Buchenwald ordeal and then were forced to leave their home and relocate to the United States. Years later, the brothers made contact when they wished to divide up their parents remaining assets. They were not successful, Adele's mother did not do so. The family members remained on non-speaking terms until their deaths. The Holocaust impoverished and rent their family in three, if not more, directions.

The children of survivors never lived outside the structure of the Holocaust passed through their parents memories. In Nothing Makes You Free: Writings by Descendants of Jewish Holocaust Survivors Bukiet (2002) noted the precarious experience of being in the second-generation. He said "If you can't place yourself in the mass grave, you can't quite drag yourself out of it, either" (p. 18). Nadine was named for an aunt who perished as a little girl in the Holocaust. She, in turn, has named one of her children after another family member who was killed at that time. Names are memorializing; bearing witness as tributes to 
"keeping the memory" of the deceased ever present. Yet there is more to it. "Children of survivors were reminders of loss and symbols of compensation. Named after murdered relatives, they suggested the ever present potential for harm as well as the precariousness of those who escaped the jaws of death and promised to fill the void left by others" (Hass, 1990, p. 55).

Nadine's mother and her grandfather physically escaped the Holocaust, though they lost everything else. They were assisted by the Japanese diplomat, Chiune Sugihara, who issued thousands of visas to Jewish people as Vice Counsel in Poland-Lithuania (1939-1941), Counsel General in Prague, Czechoslovakia (1941-1942) and in Bucharest, Romania (1942-1944). With transit visas through Russia they individually made their way to New Zealand. Nadine's teenaged mother travelled first, alone with only a knapsack, because her father's visa came later. The father's plan was to bring his wife and three other children as soon as he could. However, this was not what happened. The wife and three children were swept up into the Holocaust and were murdered. Nadine's father first met her mother as refugees in a camp prior to her departure to New Zealand. Nadine's father was able to make his way to San Francisco as he had a relative there willing to sponsor him. Nadine's mother and father had fallen in love and managed to find a way to correspond with one another during their two years of separation during the war. Nadine's father lost his sister and his parents in the Holocaust. By the time they reunited, nearly all the family they had was Nadine's maternal grandfather. On family heirlooms; objects imbued with memory: 
Nadine: I am afraid to throw anything away... I never know who's touched anything, you know. I feel as if a lot of it's history, so I have to treat it carefully. I have my father's visa from [Chiune] Sugihara. I have a broken-down children's book that belonged to my mother's little sister from Poland.

Both the second-generation and their survivor parents have corroborated the parents' memories against documentation and available analysis. This process has not reworked their memories, but has allowed insertion of factual dates, for example, of the decision to "liquidate Jews." Then the family history is placed on a timeline or continuum of sorts. As Stein (2009) pointedly wrote, this is rather imperative: "Late modern societies require individuals to construct coherent, continuous biographical narratives" (p. 293).

Sarah said as a young child she understood there was a difference between her American mother and her survivor father.

As a child I can remember sometimes people would talk about [the Holocaust] and the thing that I remember the most is that occasionally there would be a telephone call and I could hear my mom saying it was such and such a person who knew your parents or knew you from a concentration camp or something like that. And, I remember my dad would say "no" he didn't want to talk to them. And, he wanted nothing to do with survivors at that point in his life. But he was always reading everything he could about World War II and the Holocaust.

Marilyn was not intentionally left out of the theme of loss. At this point, in her interview, she cried and we turned the camera off. She cried tears of 
frustration, tears of grief, and tears of loss. Tears, in themselves, are not indicative of pathology, but are a healthy response. Yet, the second-generation are rightfully considered a vulnerable population and there is no way to "fix" the devastation caused by the Holocaust. What we must recognize is that in intergenerational loss, the second-generation experience this in two ways: 1) loss as it impacted their parents, and 2) loss as it impacted themselves. For both generations it is the absence of someone and loss of something. Thus, the secondgeneration, who were not living during the Holocaust, have voids in their lives without ability to recover what, or who, was lost. This is complicated by the fact they never knew any of the people, such as grandparents, who were murdered, and the second-generation may have few surviving photos or other mementos of the past. A companion to loss is the heightened importance of the small items which have survived, such as, Nadine's deceased aunt's "broken-down" book.

\section{On Being Second-Generation}

For this study, the fourth theme is positive impact, or clearly positive aspects in being second-generation. There is pride to have overcome great odds, acknowledgement of being adept at handling grief and loss, and expressions of resilience beyond many others in the general population (though the participants did not directly offer such comparisons). There were warm expressions of care and love for their families, including siblings, though David and Rebecca do not have a sibling. Also, the concepts of forgiveness and reconciliation were lightly touched upon. Yet, we must not fail to keep present: 
In a way, life has been even stranger - though infinitely less perilous - for the children than the parents. If a chasm opened in the lives of the first generation, they could nonetheless sigh on the far side and recall the life Before, but for the second generation there is no Before. In the beginning was Auschwitz (Bukiet, 2002, p. 13).

Adele repeatedly said she was proud of her family. Her family tree includes diplomats, ambassadors and two Nobel Prize winners. She has a bound book of her family tree. There are women mathematicians, physicists and other scientists in male dominated fields. The tree also includes a number of people whose names have "Hitler" written in beside their names as they were murdered in the Holocaust.

Gloria is the oldest of four children. She repeated her comparisons to other American-born school children where noticeable differences continue to have resonance. Her school friends had grandparents and history here in the United States. She did not. "I don't know, maybe it was just things that [my mother] had said to us, we never really, my sisters and I, never really understood where we came from."

Gloria: I don't know when the first time I heard the word Holocaust. I really don't remember. Because I do know that I heard the word Holocaust before I understood what had happened to my parents. Because I kept thinking, Holocaust, okay, that happened to Mom but here she is, she's fine, it couldn't have been that bad. [She shakes her head in disbelief.] And, she never did 
anything, you know, she never said anything one way or the other. So I didn't have an understanding of the full story until I was an adult.

As previously mentioned, Nadine said she does not remember not knowing about the Holocaust. It was a part of her everyday life. Her father, a Holocaust refugee, became an Ivy League professor. She referred to her status as a "faculty brat." Her grandfather had also made it out of Poland, but most of the other relatives were unable to get their families out.

Nadine: So, there were no cousins, no aunts or uncles in my parent's generation. There were just old people who made it out without their families. They all would get together and talk Yiddish and [being survivors] was obvious. To me it was just always part of the scenario. And, it wasn't something that made me sad as a kid other than I had no cousins and other people seemed to have them. It was just the structure of my family. It's what was normal.

The second-generation learned more than what it means to be Jewish, or precisely because they are Jewish; they also learned life skills, which to repeat Hass (1990): "[Parents] suggested the ever present potential for harm as well as the precariousness of those who escaped the jaws of death and promised to fill the void left by others" (p. 55). Parents who had survived the Holocaust wanted to be certain, in an uncertain world, that their progeny would possess the best life skills possible so that in the advent of another Holocaust, the children would be able to survive. 
Rebecca's father, who worked in the Nazi laundry and managed to get lifesaving extra bread, cigarettes and even chocolate through his ingenuity and ability to push the limits without getting caught or killed, imbued her with a strong ethic.

Rebecca: My father was very smart about having exit strategies knowing how to get out of things. Think three steps ahead. Sometimes it's hard for me because I can't be in the moment because I'm always thinking: "Okay, well if this doesn't work out, I'll take that path or this route." But it's a way of survival. So, I inherited a richness from him in terms of effort, work ethic, integrity, ethics. Helping other people, the bigger picture, material objects versus the importance of life. Living every day.

Sarah spoke to the importance of survival skills in application to her own life in a time of personal upheaval and trouble. When she was going through a particularly difficult period, she summoned up "some of that survivor instinct." She said her father had not verbally taught it to her, but that "he modeled" it.

Sarah: I picked up from my father and my mother how important family was. And, [my father] didn't have a lot of close friends. But when my children were born, that was the best of everything. He valued family so much. He would say, "When you've lost your family - this is all we have."

Ben spoke of love and respect for his sister, his survivor mother, and his refugee father. He marveled at his mother's generosity for most of her life, though again, noting the language barrier, and then dementia in her final years. Like Rebecca's father, Ben had an uncle who stole bread which he smuggled to 
Ben's mother, keeping her alive. The uncle, Ben never met, perished in the Death March [Fall 1944-April 1945] or in a transport at that time. He is not quite sure.

David studied warfare and weaponry at a liberal arts college and wrote his thesis promoting the use of advanced weapons systems which, in his view, would reduce the overall number of deaths were there to be another war. However, he has focused his life's work specifically on the Second World War and the Holocaust.

David: I first started studying the war. And the different campaigns and how the countries were conquered. And, also how they were finally liberated. I thought it was important to know [be]cause if it wouldn't be for Hitler conquering all of those countries, if it would have just happened in Germany, the Holocaust would have been a lot smaller. And, because he conquered all those countries, he had the chance to try to kill all the Jews in those countries and the Holocaust was a lot bigger.

Joseph spent much of his interview speaking about his friend, Holocaust survivor Alter Wiener. In a sense, Mr. Wiener is a familial figure. Joseph believes that his own parents would have been "exterminated" had the Nazis caught them.

Joseph: ... [Alter Wiener] has taught me so much philosophically about life in addition to so much about the Holocaust and the importance of remembering and documenting what happened. And counteracting the deniers who are just nuts. We need to keep teaching this so we can counteract their venom and counter anti- 
Semitism and, and all kinds of prejudice everywhere. Alter's conviction is that all the problems in the world are due to prejudice. And, if we can eliminate prejudice worldwide, there'd be no need for war. And, he's right.

Karen was the only second-generation person to mention the concept of forgiveness. Speaking to memory and the mixture of knowledge which comes from one's parents, Karen went right to the point.

Karen: My Dad was very frugal, very thoughtful, more on the quiet side. [He] loved to read. [He was] very patient and as far as the Holocaust goes he would always say: "Don't hate, you know, hate is an emotion that drains you and distracts you and takes away from your life." So, you just move on. He didn't necessarily talk about forgiving, but he just said: "Don't focus on the hate." My Mom was very outgoing and energetic. She loved nice things [and] music. She was very strong-willed, so I got a good dose of a mix of both, kind of opposites.

The only other person who mentioned the theme of reconciliation was Marilyn. Forgiveness and reconciliation are not the same, but are both components of conflict transformation. Tint (2009) says: "While forgiveness is typically regarded as an internal process for those who have suffered injury or trauma, reconciliation is seen as a process where parties come together to repair injured relationships and fractious histories" (p. 274).

Marilyn did not mention Tint's work, but was very concerned about peacemaking and peacebuilding and referenced The Anatomy of Peace: Resolving 
the Heart of Conflict (2006) by The Arbinger Institute. This book follows a reconciliation workshop co-taught by an Arab man and a Jewish man each of whom who lost his father due to the actions of the other's cousin. Their ideas center around listening, educating, building relationships, building relationships of influence, "getting out of the box," and having a peaceful heart.

When Ben was speaking about being second-generation he repeatedly brought up world events, such as, the Clinton administration's actions in Serbia, and present-day Syria concerns. [Serbian President Slobodan Milošević charged with war crimes (to include genocide) died in his Yugoslav prison cell in 2006.]

Ben: I don't remember exactly back then what the political climate was but, you know, as a Jew, I thought it was wonderful that he did this [Clinton going into Serbia.]. Because I think we were the only country that did it, if I remember correctly, and I just have this feeling the same thing is going to happen with Syria right now is that the U.S. and maybe France are going to be the only participants to stop this. I know people think we're the big brother trying to make peace throughout the world but nobody else is going to stop it. And, so I was very proud that Clinton went in there because some of those individuals have a history of being, you know, their past generations of being survivors and being killed during the Holocaust. So the fact that he was trying to stop this genocide from happening, I've got to give him credit, for that.

In the theme of positive impact, we see the outward looking gaze of the second-generation: Adele's family with her Nobel Prize winners and others, Gloria and Nadine speaking of not knowing and knowing about their own family 
history with the "normalization" of being second-generation, Rebecca and Sarah discussing survivor life skills learned from their parents, Joseph speaking about the end of prejudice saving the world, David and Ben speaking of the military and U. S. intervention to end genocide, Karen and Marilyn speaking of forgiveness and reconciliation to usher in peacebuilding. All in all, the second-generation here have a keen sense of working toward a better world through their own personal agency. Hass (1990) says "Where and how one chooses to focus one's attention will affect one's self-image" (p. 167). The outward gaze is important.

Sometimes It's Difficult, but I've Always Felt Honored

For this study, the fifth theme is negative impact, or clearly negative aspects in being second-generation. Several participants noted issues with a parent, or others, which negatively affected them growing up. This runs the gamut from feeling like a non-person, to the sentiment of not being included as a second-generation person, to wishing there had been more time with the parents, to noticing a paradigm shift in being second-generation over the years. Of particular import is an incident related by Marilyn, as a child, who did not see the words of another child as being anti-Semitic, and yet, were they not? There is some conflation here with Marilyn being both second-generation and Jewish, yet, children are taught before they speak. We know it is not all in the past and one second-generation parent recently experienced an act of anti-Semitism, without recourse, against one of her teenage children. 
Gloria said it was difficult being the first-born child (1950) so soon after liberation. "I felt as a non-person because their memories of their past were a lot more important than me growing up. And, I always felt that I couldn't fault them for that. You know, I mean... even being young I could understand." She elaborated:

Gloria: But, and then as a young adult my Mom started speaking out and lecturing about the Holocaust. I was happy to do what I could for my Mom because she got so much out of being able to share her story with others. That was so healing for her. And, it was wonderful to see. She became a much more whole human being. But, now it's: "Now you should go out in the schools and talk about it and everything." And, it's: "No. I've lived it all my life." "Leave me alone." "I know about it." If you want to come and ask me questions about it I'll be happy to talk with to you. But, no, I'm not going to pack up and go and speak. Speaking in front of others is not as rewarding for me as it was for Mom, and, it's okay. Because there are people that will do that. The information is there. And, it's up to teachers to teach some good lessons because it's not just about "The Holocaust." It's about all manner of prejudice.

Gloria's memory of her mother becoming a "whole human being" in the process of speaking out to audiences is a very important part of trauma and memory. Brison (1999) wrote "Memories of traumatic events can be themselves traumatic: uncontrollable, intrusive, and frequently somatic. They are experienced by the survivor as inflicted, not chosen - as flashbacks to the events themselves" (p. 40). The following might easily be applied to a second- 
generation person as well as to a survivor. Brison said "narrating memories to others (who are strong enough and empathetic enough to be able to listen) empowers survivors to gain more control over the traces left by trauma... and helping a survivor remake the self" (p. 40).

Gloria has been able to assert herself from the context of her mother (and perhaps societal expectations) by choosing not to engage in public speaking about the Holocaust, her parents experiences and perhaps, even her own. Marilyn experiences the social environment as much better now, but another interviewee's son had his school year book defaced by swastika's in all different colors and types of pens. The sole relief mother and son were provided was an opportunity to purchase a new year book. Anti-Semitism still exists.

Marilyn: Being Jewish, personally I didn't have any trouble. At one point our next door neighbor kids who were Catholic and went to the Catholic Day School came home one day and said: "The Jews killed Jesus." And, "You killed, not the Jews." "You killed Jesus." And, I'm like: "I never, I don't have a gun. I never shot anybody. I don't know how to do that." But we were friends. We still played together. They were learning things in their school in those days. It's different today. It's much better. The kids are more inquisitive. They're finding out the facts. I am not prejudiced and I am proud to be Jewish. My friends all thought it was cool. So, I never had one bit of trouble otherwise, growing up.

Joseph said that there was not anything hard about being secondgeneration because his parents were not "technically" survivors as they had been 
refugees and were never "incarcerated." His parents had individually fled Vienna in 1939 and Joseph thought that, at the time, no one knew how bad it was going to get. But then, he also quoted: "Every Jew was a victim, but not every victim was a Jew." So we may see some ambivalence and/or discomfort in his response. His parents are definitely included as survivors.

Adele said the hardest part of being second-generation is that she did not ask enough questions of her parents. She said "I don't feel I know enough." She did not ask her refugee mother the questions she wishes she could have. She explained that she was so preoccupied with her own busy life, she didn't think to ask and each of her parents' deaths were unexpected.

Karen said she did not find it difficult to be second-generation and noted that many people find it motivating to help others and do volunteer work among other things. She said they're "compelled and energized to do something." She said she has seen other second-generation people who have struggled, but she thinks this is more about family dynamics. It is not difficult for her.

Memories and attitudes become refined through the years. Nadine spoke of having different difficulties at different stages of her life. The interviewees for this study are in their middle years and were born within a thirteen year span between them, and their parents are now deceased. Klein-Parker (1984) found in her research with older second-generation a "shift from guilt and shame to pride 
and appreciation an increasing recognition and admiration for parents' attributes which enabled them to survive..." (Hass, 1990, p. 88).

Booth wrote about the inherent ability to revise memories as we experience a new outlook: "... We always see the past from the vantage point of the present, and from its needs and conflicts. The contours of our appropriation of the past change, then, according to what presses in the here and now" (p. 67). At this juncture, we must realize that "... the past... must be called into existence, put into words, or commemorated in stone, provided a vocabulary that will allow it to emerge. Indeed, among its original significations, the classical Greek word for remembering, mnaomai, meant to mention something to someone" (Booth, 2006, p. 67).

In Nadine's case, she is not an adolescent, but the mother of teen-aged children. Her concerns are not so oriented toward looking back, but instead, looking into the future with the past.

Nadine: The hardest part [is] to realize the immediacy is fading. Historians could keep it alive but it's not the same thing as having known the people who were involved in [the Holocaust]. And, that's what happens. People who survive eventually die just like everyone else. And, at some point there won't be any signs of it. I know that my mother always made a point of showing the pictures. When she was interviewed she would always make a point of showing the pictures of those who were lost because she said the same thing: "People will forget what they looked like. They were real people." 
Not one person connected with this research expressed malice or hostility toward others for the Holocaust. Instead the articulated desires were to educate others against the dangers of anti-Semitism and prejudice for all people. Marilyn offered the story of a school child listening to her mother's presentation. The child asked: "Do you hate the Germans? Aren't you prejudiced?" And, the survivor's response was: "No. Just anybody who commits a crime should be punished."

Nadine's concern for forgetting is acute. She was worried that if people forget history will be repeated. She offered education as an antidote to forgetfulness. Aristotle said: "The roots of education are bitter, but the fruit is sweet." Ben echoed the issues of forgetting and the consequences of doing so as he spoke about the hardest part of being a second-generation person:

Ben: I think one of the problems is that people tend to forget and humans have a tendency to not remember what went on in the past and that these things could happen again. In terms of a genocide it happens. We see it throughout the world and people tend to forget how inhumane humans can be to others. .

Berger (1997) said the second-generation are being held up to become "superachievers." Berger in his discussion cited a dialogue from a son to his father in Elie Wiesel's The Forgotten (1992): "You'll have to forgive me, but I'm going to disappoint you. There is no such thing as a memory transfusion. Yours will never become mine. I can live after you and even for you, but not as you" (p. 18). 
Rebecca: I think that the hardest thing is just that is that there were great expectations. I think that, for my father and even for my mother who wasn't a survivor, that there was this great expectation to me to make something of myself, to be successful. It was sort of the Jewish expression of naches [Yiddish word meaning a child bringing pride and joy to the parents] which is to pleasure or... and I think that there are high expectations on the part of Holocaust parents that their kids really do something in their life, be something in their life, achieve something because there were so many people [who] were lost during the war.

So I think, as a result, there are great high expectations and sometimes it can be very, very much a pressure cooker. And I felt like there were a lot of expectations that my parents had of me and I couldn't fulfill all of them. And, I think that - that was probably the hardest because all of it was riding on me. And that may have been partly that I was an only child; perhaps if I had had brothers and sisters maybe it would have been more diffused.

Sarah missed her parents more than anything and specifically her father. He died at age fifty-nine. He had survived the Holocaust, but walked into the path of a car which Sarah said was his fault. Succinctly she said: "He was a survivor, but he didn't live long."

Sarah: Well, I think just the fact that maybe I don't know all the details, that now as an adult and that he's no longer here, I wish I did. But I was in a survivor group maybe ten, fifteen years ago and they were mostly people my age, and they decided (their survivor parents were still alive) to hire a therapist to come to the meetings. And, I dropped out at that point. Because I don't feel I was scared 
at all by my father being a survivor. I grew up in a loving household. I knew I was loved. And, I now know there were some little quirks about my father that come as a result of his experiences but, I don't think there was a hard aspect, because I did have such a loving family. Losing them was probably the hardest.

Ben remembers his loving parents and how he learned generosity from his mother and patience from his father. With a broad smile and a lot of laughter, Ben recounted the way he indirectly learned patience as he would simply wait for his father to stop lecturing him, noting his sister was the "good daughter" who never got lectured. Ben said his father instilled in him the idea: "Go out there, do the best you can, but don't expect to win. But if you do win, then it's even better."

Ben: One of the things about growing up was that, again the Holocaust was never really mentioned very much at all and when I read that book about children of the Holocaust I really could not identify with it at all. [Epstein, H. (1979). Children of the Holocaust: Conversations With Sons and Daughters of Survivors.] Because here's this woman talking about all of these psychological and mental problems that she was having growing up. She ascribed to having all of these psychological problems because of her parents were survivors. I never had any of those problems at all. So, I don't understand what she went through. Because I surely didn't go through any of that. I had a pretty normal upbringing, nothing dramatic or traumatic at all. Pretty average.

To say that Epstein's work was ground-breaking is not enough. Berger (1997) noted that "the odyssey of Epstein's book reveals much about American culture's changing attitude about the second generation" (p. 17). He said that 
some people call her work the second-generation's "Bible." Nevertheless, her work did not have resonance for all second-generation. The participants in this study particularly rejected the identity of pathology. Given the sheer complexity and uniqueness of all of the people of this generation, and of their parent's generation as survivors, it is not surprising that one study does not fit all. What is important is that people did read it. Epstein's book is, and will probably always be, a touchstone for the study of the second-generation. She opened a dialogue which led to the creation of many second-generation support groups, conferences and other modes of connection between those born post-Holocaust.

Ben learned patience from his father while David and Rebecca spoke of some of the other positive effects of being children of Holocaust survivors.

David: With my father, you know, he was telling me stories from the age three forward and, like I said, I was very honored that he was telling me these stories at such a young age and I never found anything hard about it. If anything it, it, it was a moderate experience. Not good or bad. And, sometimes you feel in an honored position because you could tell stories to your classmates, you know, from first grade all the way forward, which nobody else could do. And, it made you sort of stick out, you know, and so, I felt sort of honored to be in that position... It was anywhere from a neutral experience to being positive in the way, that you felt honored.

Rebecca articulated what others implied for the acceptance and emphasis on what really matters in life. She said that being the child of a Holocaust 
survivor lent: "A great appreciation of life of the fragility of life. The recognition that all of the material things that many Holocaust families ultimately achieved, post-war, are really not that important in the scheme of things if you don't have your family."

Examining the theme of negative aspects for the second-generation, and concluding with Rebecca's affirmation of life, is indicative of all of the participants of this study. From Gloria, who struggled with feeling like a nonperson, perhaps until her mother blossomed into a "whole person," to Joseph who currently feels like a non-second-generation person to second-generation who are "energized" for volunteer work, we see separate identities within the secondgeneration. There is not a "typical" second-generation person and concepts of being second-generation have evolved over the years since the Holocaust. There has been a paradigm shift, as Klein-Parker noted, from guilt and shame to pride for a large number of the second-generation. A caveat remains that anti-Semitism continues to impact the Jewish people in acts that may be without recourse.

\section{Media and Memories}

The sixth theme of this study is media. Media, or what might sometimes be "mediated memories," can be an art form, though it is relatively clear that most mass-produced media is, from time to time, a commercialization, in dramatic format, of historical events. Media is largely profit-driven. When it comes to the Holocaust, the pejorative phrase Shoah business is tossed about and other potentially denigrating phrases are survivor tropes, trauma tropes, trauma culture, 
and misery memoirs (Ball, 2015; Radstone, 2008). Most media is designed to elicit emotional and cognitive responses in the viewer. For some viewers commercialized media can be cathartic or evocative, and for the secondgeneration, observing their parents viewing media fare, may have answered some questions by leading to previously hinted at, but unidentified, insights.

Ben, Gloria, Marilyn, and Joseph spoke about memory, media and the Holocaust. All four remember watching their mothers' reactions to dramatizations of Nazi and World War II themes on television or in film. These experiences gave the interviewees an insight to their mothers' experiences of the Holocaust. All four described not being able to ask their mothers the questions which were answered through the medium of television, documentary and film. Given the power of media, it is apparent that accuracy is extremely important.

Ben: ... [In 1985] we watched all nine hours of [Shoah] over two days. [Shoah (1985) directed by Claude Lanzmann is Lanzmann's self-professed art film on the Holocaust portraying the perpetrators, the liberators, the bystanders, and historians.] That was pretty gut-wrenching, but a lot of my questions were answered. I couldn't ask my mom these kinds of questions. But luckily the movie was able to answer a lot of the questions. And, I remember when Schindler's List [1993] came out. And, I guess my sister had bought a copy of the movie for my mom and I guess they were watching it. I didn't, I wasn't there at the time. I guess they were watching it and all of a sudden [mom] said: "Turn it off." And, [my sister] asked why and [mom] said: "That's not the way it was." She said: "It was much worse." And, she didn't want 
to watch the rest of it. So, what they portrayed was just barely scratching the surface.

In GI Jews: How World War II Changed a Generation Dash Moore (2004) describes the reality media cannot define. She describes what the liberators found: "An enormous pit, filled with bodies. Stick-like arms and legs protruding at odd angles. The stench was overpowering. And before our brains could even sort out what we were seeing, there were the sounds - plaintive mews, groans penetrating our consciousness. And then the final horror - these were people and some were still alive" (p. 227).

The large screen has not been the only vehicle for the depiction of the Holocaust. Countless television programs have had episodes about the Holocaust. There have also been made-for-television movies and documentaries. The medium is potent and capable of eliciting real emotions from viewers and distinctively capable of triggering memories. Gloria and Marilyn, separately, offered these memories of their survivor mother:

Gloria: I didn't find out, you know, details until I was an adult, married. And, she had written a book and given all her daughters a copy of the book. And, it's like "OH." But we knew before then that there was something that happened, but no details you know, mom had... she was always interested in watching the war movies on TV [television]. You know, the movies about World War II.

Marilyn: ... About the seventh grade, mom used to always watch Combat [1962-1967]. It was a war show and one time I sat down with her and I said: "Mom, why do you like to watch that?" And, 
she said: "I like to see them get the Germans. I like to see them get the Nazis" Okay, let it go, that was it. And, then, in high school, we did have a unit where we had to watch movies and some historical clips [which] must have been during the Holocaust, but I thought to myself: "I never learned this in [Jewish] Sunday School and I went every day, every week, every Sunday. I went to Sunday School for eight years straight. [Be]cause I liked getting the one hundred percent attendance pin at the end of the year, so I always went. And, really, [my parents] never talked about it.

Media can bring viewers to tears. Not only do people empathize, but memories may be triggered. Joseph's parents were refugees who barely escaped the Holocaust.

Joseph: [As a child] I have very distinct memories of my Mother, sitting there watching [a televised] documentary crying, never said a word, just crying, crying and crying. And, that left a very deep impression on me that there's something important here, something awful happened. It took years for me to realize: Oh, that's what happened, [the Nazis], you know, tried to take over all of Europe and did take over Austria and Mom and Dad and everybody else had to flee. And, they never said this specifically but I finally got it: Oh, they were refugees from... the Nazis. If they hadn't been lucky enough to get transportation out, in those two different directions [to England and Italy on their separate ways to the United States], there's no doubt that they would have been captured and, exterminated.

Joseph's use of the word "lucky" is in a similar vein as Ben's prior use. It is a word which should be used cautiously in the discussion of the Holocaust. As 
previously noted, Joseph has a film in the works inspired by Alter Wiener's book From a Name to a Number: A Holocaust Survivor's Autobiography (2008). He gestured to the book and said that the number 64735 shown on the cover was marked on Alter Wiener at his fifth and last concentration camp, Waldenburg in Germany [Waldenburg was a sub-camp of Gross-Rosen and became part of Poland]. Later Joseph would also comment that Alter Wiener already has his tombstone carved with the inscription: "Ignorance is the enemy of mankind."

Joseph: And, so I have fallen in love so much with [Alter Wiener] and the lessons and the power of his life story. For example: "Every Jew was a victim but not every victim was a Jew" the way he tells that story is so poignant. I've fallen so much in love with it and I've seen how it changes other people who hear his story or read his book that I've dedicated the rest of my life to helping him promote [his] book now and after his passing. And, I have obtained the movie rights from him so that I can make a feature film which will hopefully be a big deal like a Schindler's List [1993] or The Pianist [2002] type of movie and, share this story with the world.

Joseph is definitely seeking the positive attributes that a motion picture might offer, but there is another element to media to be noted which goes to an inspirational quality of the media as with Marilyn's mother.

Marilyn: What I witnessed was mom [who] would drop us off at dancing lessons or piano lessons and stay in the car to scribble on her pad of paper. And, I didn't ask her what it was. But later I found out she was writing down her memories [be]cause she had 
heard on TV [television] a talk show that: "If you have something you should write it down..." "You do not have to be a perfect speller or a perfect linguist. Just pour out your feelings on paper." And, that's how she wrote her book.

Recalling Radstone and her discussion of trauma or wound culture, in the company of both ethics and politics, it is important when we consider that we are risking what she sees as "pitting" an educated middle class culture against popular culture. In this discussion of media and memories, the second-generation in this study are all college educated, plus, they have independently studied the Holocaust. Radstone is specifically concerned about cultural elitism (p. 36). The issue arises when we might try to compare a television program, such as, Combat, with a documentary, or with the Lanzmann art film Shoah. The participants of this study are not cultural elitists, but being educated, are striving for accurate historical education for all people. In the end, it is persuasive that Ben, Gloria, Marilyn, and Joseph all learned more about their mothers' Holocaust experiences through media representations, whether commercial or not.

\section{Speaking of God and The Jewish Tour}

In this study, the seventh theme is faith. Some participants spoke of their beliefs, others did not. Some of the respondents discussed Sunday school during their childhoods, being the only Jewish family in their neighborhoods, and, in their turn, raising Jewish children. Hass (1990) wrote an evocative chapter titled "Can I Believe in God?" and shortly said, "The idea of God is not a comfort to me, but a taunt" (p. 145). He has an erudite discussion of the meaning of faith, 
what has been done in the face of faith, being of the Chosen People, and in the end, believing in a Supreme Mover, but wishing for a sign (p. 153). His questioning is succinct: "Ultimately, how do I move beyond a narrow definition of Jewishness predicated on being a member of a group that was purposefully persecuted and almost annihilated in an unprecedented manner?" [italics his] (p. 152). Nadine, Ben, Marilyn, Adele, and Gloria shed insight into this query with their recollections and their Jewish Tour experiences. Both Ben and Nadine's parents were from Poland which has been a hotbed of Catholic anti-Jewish virulence before, during, and after the Holocaust, including the charge of deicide against the Jews. Marilyn and Gloria's mother [also Karen's mother], though not Polish was in Poland, incarcerated in Auschwitz .

Nadine: When I was about five I remember some kid maybe at preschool or kindergarten or something had asked me if I believed in God and I said: "I don't know." So, I figured I would ask my mother. And, I did ask my mother if she believed because I figured that would probably tell me whether I believed. And, she said: "No. What has he ever done for me?" Of course, she was thinking not about her child sitting in front of her, but about everything she had lost.

Noting the effort his family put forth to ensure their children were raised observant, Ben, nevertheless said that religion was simply not that important to his parents. So, Ben notes an ambiguous relationship with religion, though it still matters: 
Ben: I had a Jewish upbringing and still feel very Jewish. Married somebody who is Jewish. My sister married a Rabbi. His father's a Rabbi, his uncle's a Rabbi, his son-in-law is a Rabbi... They're very religious, they keep kosher... we don't... But my wife is, is fairly religious. We do Friday night Shabbat in our house every night that we're there. I am more of what would be described as a cultural Jew and not a religious Jew. My wife's much more religious than I am. We don't belong to a Temple here but, we celebrate the holidays. Rosh Hashanah is coming up so we celebrate that. We fast during Yom Kippur. And so we had, you know, not a religious upbringing, but it was very much a Jewish upbringing and, I was easily able to identify with being Jewish.

Nadine also wanted to raise children who are able to be stewards of the family history and, most importantly, to be proudly Jewish. Her teenagers are her concern:

Nadine: When I was [my children's] age I am not sure I understood either. How important it was. So many people died so we could be Jewish and, that's still the case, but with every generation the immediacy fades. It's important that people follow their own drummers, and love is where you find it and all that stuff, but it's scary to hear the statistics about people not carrying on their identities, their sense of being Jewish. I am not a religious person, but I know who I am and hopefully raised my kids to know who they are. It remains to be seen.

It is noteworthy that fourteen days prior to Nadine's interview she had read the PEW Report on American Jews (released on 1 October 2013) which reported that intermarriage for Jewish people was at an all time high for the years 2005- 
2013, with fifty-eight percent of the respondents not having married a Jewish spouse. This was very much on her mind throughout the interview.

As is apparent, the second-generation are multi-faceted and unique. No two people are the same nor have the same experiences of the Holocaust memories of their parents nor of their childhoods as children of survivors.

Marilyn: Well, generally second-generation, it's not really like being the Chosen people, but it kind of like is. Because it means that the second-generation really do owe society their family stories. They'll get lost otherwise. And, I don't think anyone really cares as much as the next generation of anything, of anybody who has been through a crisis. We owe that to anyone who is interested to know. We need to be able to share that story with them.

The Chosen people: the origin of these words is from the Torah and the Christian Old Testament. Berger (1997) calls the Jewish second-generation, the Children of Job. He said: "Affirming who they are, second-generation witnesses shed light on contemporary Jewish identity" (p. 20).

The focus of second-generation witness testimony is less on the Holocaust itself than on its continuing aftermath. The beatings, torture, humiliation, gassings, and burnings happened to their parents' generation. It is the survivors who remember living with death and routinized evil as constant companions. With the messengers who brought fateful tidings to Job, they can say, "I alone am left to tell you" (Job 1:15, 17, 9 quoted in Berger, 1997, p. 2). 
Adele spoke about a trip with her mother to Germany as punctuated by a visit to a restaurant. The waitress took her mother's order and then turned to Adele. This memorable moment still resonates as Adele, to the waitress' surprise, does not speak German though her mother did perfectly. Most of the secondgeneration are in a sense separated from their parents through language and also do not have the European accents of their parents. Maurice Halbwachs (18771945) [died in Buchenwald where Adele's grandfather had been incarcerated] wrote: "... Verbal conventions constitute what is at the same time the most elementary and the most stable framework of collective memory" (1992, p. 45).

Ben "did the Jewish Tour" back to his mother and father's native land, Poland. He reported it was a discomforting experience as they traversed the towns and sites where his mother had been. While the discussion of loss is very important, the memory of the forests for Ben is quite striking. This is not uncommon for the children of Holocaust survivors nor for the survivors themselves. The solitariness cannot remain peaceful as one recognizes the isolation from the nearby towns and how helpless the victims were with the Nazis. Later at Auschwitz, Ben said going there was like "going to a funeral."

Ben: I was an emotional wreck the entire day. I remember. But it was nice, it was wonderful to be with my sister, together. It was wonderful to be with my wife and my brother-in-law, who's a Rabbi. So, we said Kiddush [a holy prayer] at the crematorium - at the remaining crematorium that's there. And, that was kind of the most emotional part of the entire trip - was paying our respects to 
our family members. And, that was really the main purpose of going there was to do that. It is so hard to believe that humans would do [that] to others. It was beyond belief. And, I think that's why as second-generation children we have to continue to remind the world of that.

Ben noted the prevalent anti-Semitism they encountered, combined with the absence of Jews, in Poland. Gitelman (2003) has written: "It is relatively easy to explain why Poles and Jews disliked each other in the past. It is more difficult to understand the persistence of such sentiments more than half a century after over 90 percent of the Jews of Poland were murdered and when only some 5,000 to 10,000 are left in a population of about 40 million" (p. 272). The ease to which Gitelman refers to has its roots in the teachings of the Catholic Church. Poland is staunchly Catholic and virulent anti-Semitism existed prior to the Holocaust. The Catholic Church had taught that the Jews practiced deicide and were thus guilty of mortal sin. Gitelman cited a letter by Cardinal Hlond spoken aloud at all Polish parishes three years prior to the Nazi invasion:

A Jewish question exists and there will be one so long as the Jews remain Jews. It is an actual fact that the Jews fight against the Catholic Church, they are freethinkers, and constitute the vanguard of atheism, bolshevism and revolution. The Jewish influence upon morals is fatal, and the publishers spread pornographic literature. It is also true that the Jews are committing frauds, practicing usury, and dealing in white slavery. It is true that in the schools, the Jewish youth is having an evil influence... upon the Catholic youth (p. 273). 
As this Polish world view persists today, it is instructive to note the Second Vatican Council (1962-1965) partially dismissed the idea of Jewish deicide. In 2011, Pope Benedict XVI published his book, Jesus of Nazareth II, "clearing the Jews" of deicide. [The Pope Emeritus' birth name is Joseph Ratzinger (b. 1927). He was in both the Hitler Youth and conscripted into the German army during World War II.]

Gloria also did the Jewish tour with her sisters and mother, visited Auschwitz and surprised some people by not behaving as expected. Errors are made without asking questions. Thankfully someone asked for clarification.

Gloria: We spent the day at Auschwitz with mom: "And this is where this happened, and this is where this happened and this is where the men in overcoats, they were taken in that building and we never saw them again..." And, we're listening to all of this and but then that evening, we're laughing and having a great time and somebody came over and said: "How can you be so happy?" We kind of looked at each other and I just remember looking back at him and saying: "Because we're here [alive]. You know, we weren't supposed to be. But we are. And, we are happy that we are here." So, it's, there's always, you know, part of the Holocaust experience that is probably part of everything that I do.

It is important to note that none of the interview questions asked about faith. These reflections were spontaneous and added so much value to this inquiry as, on the whole, the parents of the second-generation and their families were targeted in the Holocaust because they were Jewish. Nadine's mother saying 
she did not believe in God to her young daughter strikes a chord. Post-Holocaust it is an important issue for the entire Jewish Diaspora And, yet, there have been persecutions of the Jewish people through the millennia It is difficult to understand the continuance of anti-Semitism and the recurrent question of deicide. If we recall back, Marilyn, as a young child in the United States, had been accused of deicide by a young Catholic child who was her playmate. Why?

\section{Education is Life Itself}

The eighth theme of this study is education. Recalling Zerubavel and the concept of mnemonic socialization, the family is the first thought community for the child to first learn their beliefs, values, and habits. Relying solely upon this approach is insufficient in terms of conflicts, wars, and genocides, such as, the Holocaust. Thus, the Holocaust in memory, intergenerational impact, and historical fact, must be taught. The methods of education are varied: Knowledge is achieved through storytelling, reading, discussions, lectures, research, and experiential forms of teaching. With the present study, the emphasis is on storytelling as we read the second-generation accounts of their memories to increase our intellectual coin toward becoming skilled agents of change, and increasing the global efficacy of each person. Why should we do this? In a way, Berger (1997, p. 7) answered this query when he quoted Terrence Des Pres:

Like it or not, we are involved beyond ourselves. To be in the world but not of it, to recover innocence after Auschwitz, plainly, will not work. The self's sense of itself is different now, and what has made the difference, both as cause and continuing condition is 
simply knowing that the Holocaust occurred.... We are entirely innocent but innocence, the blessedness of simple daily being, no longer seems possible.

Des Pres was highly regarded as a Holocaust scholar and literary critic. Born in 1939, in the United States, he hanged himself in 1987. He had been a university professor for fourteen years teaching memory and the Holocaust. We cannot infer that Des Pres' death was related to his Holocaust studies, but to study the Holocaust is very difficult. Empathetic reactions might be cold chills, nausea, and tears at human inhumanity to other humans. Yet, we must study history, because, as we might fear, unexamined history can repeat itself. Dissemination of the historical information can be modulated in different levels of disclosure for children, youths, and adults, so as to not traumatize the young.

David: I like [people] to be as well-informed as possible. So, if they ask me; my advice is read big books, thick books with lots of facts, really in depth. To see them learn as much as possible. If they're close to me, especially, I try to tell them as much as possible given from what I heard from my father. Now it's been forty-nine years on my own, I've been studying and researching the World War II era of history. And, because of that, I would like to see [people] be as well-informed as possible.

Sarah's emphasis on education is reflected in everything she said. She also addressed checking one's perceptions and being aware that you cannot always take things at surface value. Rather, one needs to explore and decipher recollections and memories. The second-generation know this. Others may not. 
Sarah: Well, I think just understanding as much as we can how some of [Holocaust survivor's] mannerisms and ways of looking at things. Let me give you an example. I remember as a child that my father hated to see us cry and he would make the comment: "You don't know why. You don't know what you're crying for. Tears are not necessary." Which I'm sure other people say, too, but he just, he didn't like to see tears. In fact, if you watched a movie anytime anything happened to a child my dad was crying, he was so upset by it. And, then another thing, he thought we made too big a deal about birthdays and I never understood that until as an adult, thanks to, I think it was through the Holocaust Museum [USHMM], I was able to see the records of when they took him. Well, they took him on his sixteenth birthday... I think we can't understand what they went through but I think you can trace perhaps some of their ways of looking at life from being a survivor.

Sarah's comments on learning of one's family through research is important and one many second-generation have undertaken. Many survivor parents did not disclose certain aspects of the Holocaust experiences to their children. Sometimes this is seen in a negative light, but it seems to be more a protective measure toward the children.

In common parlance, we are apt to hear that some event is a holocaust or someone is a Nazi without any connection to the Holocaust; the 'Event.' When words, such as holocaust, are used in casual parlance, they elicit responses based in the memories of those who hear them. 
Karen: You can't deny that horrible genocides occur and that have occurred before, during, after the Holocaust which we talk about capital "H." I think that genocide as an issue is all encompassing and the Holocaust with a capital " $\mathrm{H}$ " is one of those. What I don't like is when people use that term, for political reasons when it contextually doesn't make sense. Or, if you're comparing some political thing happening and you're calling it a Holocaust when it really, on the grand scheme of things, on the measure of how awful things can be isn't really as bad as the Holocaust with a capital "H."

Gloria, Marilyn, and Adele understand the use of the word holocaust by people for other genocides. Gloria said this is really difficult for a lot of Jewish people; however, the persecuted people of any genocide have more similarities with one another than differences. Yet, for them, there was only one capital "H" Holocaust. Adele additionally noted the uniqueness of the infrastructure the Nazis built as being a distinct difference from other genocides. Rebecca also understands the use of the word holocaust for different genocides. She respects that "a lot of people hold dear the word Holocaust," but she thinks there have been other holocausts, or "full-blown annihilations of people," such as, Bosnia/Herzegovina or Rwanda. Though she said she is not offended by the use of the word holocaust, she said that each genocide should have a specific name, such as, the Armenian Genocide, the Jewish Holocaust and maybe another name for the Rwandan genocide. So basically, she does not use the word holocaust for anything but the Holocaust. 
Nadine: My mother, in her interviews, always made a point of saying there are other genocides. There is plenty of hatred in the world. Lots of people going after each other and all of that. But what made the Holocaust different was that it was all by design. Hitler consulted scientists and engineers and chemists. He used the most brilliant minds in his country to design this very specific plan to annihilate a people. And, used all the forces at his convenience to come together to accomplish this end. These [Nazis] were killing us by plan. They would go out and they would kill babies. They'd kill families. And, then they would go home and make their own babies. They didn't see the connection. That they were destroying families while they were building their own. So, yeah, I find it offensive [when the word Holocaust is used for other events]. And, especially, you know, in the more superficial use of the terms. The ignorance, the arrogance... it's appalling... it's terrible...

Joseph has learned more through the years which both changes and tempers his assessment of the Holocaust and the use of the word. He makes clear points about some other genocides and sees them as related, but not the same as the Holocaust.

Joseph: What Alter [Wiener] has made clear is that in World War II this was perpetrated by an elected government. Hitler was duly elected every step of the way. The Nazis came into power, not by force but by elections. And then that elected government had free rein, given to it by the people, to do anything. And, they did. [And] the coordinated imprisonment, forced labor and extermination is unprecedented in terms of capital "H" Holocaust. Alter [Wiener] distinguishes between something that is a holocaust 
with a small "h," you know, meaning it a terrible atrocity perpetrated purposefully on others as opposed to the Holocaust capital "H." There are other terms they could use to mean atrocities. But [the] Holocaust, it was so specific and so enormous for such a huge period of time and such a huge land mass that there's nothing like it that I am aware of.

Ben spoke of his concerns for modern history in the making and he wants to teach children more so they come into their adulthoods well-informed and able to make a difference as active citizens.

Ben: [It's important] to educate kids in elementary school to remind them that [the Holocaust] has happened and can happen again. You see what dictators do to their own people and it's not as if it's anything new. And, you know, just like what's going on with Syria today. [On 21 August 2013 Syrian President Bashar al-Assad used a neurotoxin gas which killed 1,429 Syrians (al-Assad has been the President since 2000).] On the one hand I can understand why people are hesitant to have the U.S. involved, but on the other hand he's slaughtering innocent people. I think that's why as a second-generation "survivor," we need to keep on reminding people because this thing is happening all the time and we sit back and do nothing. So, I think that's again, one of our roles not only to inform elementary school kids growing up, but also adults.

Sarah's second response speaks directly to the grave unawareness of many people.

Sarah: I taught English at high school and I taught a unit on "The Holocaust" using the book "Night" [Elie Wiesel]. And, I did what a lot of English teachers do and I put the word "Holocaust" on an overhead and I asked the students to write everything they knew. 
And, I'll never forget there was an eleventh grade boy who wrote on his little piece of paper: "Interesting word. I think I've heard it before. Sounds interesting. Maybe I'd like to go to one someday..." I think it's our mission to continue delivering this message so that people understand what it is.

The second-generation are acutely aware of perilous persecution of the innocent. They emphasized a common distinction which is made in the secondgeneration milieu: there is the lowercase holocaust and the uppercase Holocaust. Some people traced the air with their fingers to explain which one they were using Education could repair the misuse of the word "Holocaust" which the secondgeneration individually addressed. All of the second-generation participants desire people to be educated and several offered suggestions, such as, David advising reading "big books, thick books," while Sarah offered the idea of contacting the USHMM, or United States Holocaust Memorial Museum, for information, and as she was a teacher, academic studies are essential. Hopes to bring an end to genocides require that people know what happened in the past and become acutely aware of the present. Education for the participants is life itself.

\section{What Should Other People Know About Being Second-Generation?}

For the ninth theme, the specific question asked of the participants was: "What do you wish others knew about being a second-generation survivor?" This question, not unlike the others of this study, was quite open-ended, and yet, half of the responses were similar. Ben, David, Joseph, Marilyn, and Sarah all expressed that what they wished for was that others study the Holocaust. Not 
answering the question in personal terms about themselves goes to the sense of stewardship many of the second-generation hold. Additionally, there were five more responses: three personal responses, a response concerning the lost Jewish community (though the concept of the Jewish Diaspora is more definitive), and the final response addressed the issues surrounding Holocaust-era emigration/ immigration and the current immigration policies of the United States.

Karen wanted to be certain that people understand there is not just one type of person who is second-generation. She said that she did not want people to view second-generation as damaged, but rather seen in their intricacies. She said everyone "has things in their lives that make them who they are." In the end, she did not have anything in particular to say about being second-generation.

Rebecca wanted to explain more of her perspective so that others may better understand her quiet, thoughtful demeanor. She makes the comparison of her own life to that of her parents, and particularly, her survivor father.

Rebecca: I can't speak for all survivors [be]cause secondgeneration survivors grew up in a different family dynamic, but I think there's a seriousness that comes from having been a secondgeneration survivor, at least for me. Now obviously I didn't grow up in the Holocaust. But there's a tone that's serious. And so, as a result you don't take things so frivolously. There's a serious intent with a lot of things that you do. And, I think for people who on the outside, who were not exposed to that they may not get that you've had that kind of serious, contemplative demeanor. That you can't 
be so light and easy about everything because you, that wasn't the world in which you experienced your childhood.

Gloria, the first-born of two Holocaust survivors said her parents had three children before they learned to parent. Her narrative is closer to the narratives Helen Epstein (1979) shared with the world. Gloria shares contradictions and her childhood confusion with her mother in the complexity of growing up. She said her parents did not know anyone when they arrived in the United States and did not speak English. Added to this is what Gloria phrased as wondering what was real. The life here or the life before the Holocaust? She expressed childhood confusion over these questions.

Gloria: [Growing up] was not easy and especially for my mother. She had I don't want to say suppressed [but] I think she really lost the memory of what had happened to her. She was very confused. I remember as a child, she was saying that we needed to go to New York because she knows that her mother is there somewhere. Hearing this as a young child I thought: "Why would you not know where your mother is?" Turns out that her mother was sent to the gas chambers as soon as they arrived in Auschwitz. But she was not ready to know all of that when I was really young. Having parents who were troubled like that is not easy for a child to grow up with. Especially when a lot of their love and devotion was still left with the life before the war.

Adele pointed to the fact that people can come to knowledge through their own pursuits. She said that rather than look at her, she would prefer people look 
at the vibrant Jewish community which was taken away because of the Holocaust. She wants people to know more about what life was like back then.

The "continuing aftermath" of the Holocaust informs us that this period of history is not really behind us, but lives on through the people's lives who were touched, nearly touched by the experience or empathetic to the Event. Some aspects of this effect can be applied to other genocides and/or other peoples.

Nadine: I wish others were closer to the immigrant experience and brought some of that to bear on their political views about immigration. It's just not always that easy to get to the U.S. and not everyone has the resources or the connections to do it by prescription. The St. Louis was turned back and what happened to those people? Okay, so they would have been illegal immigrants, but they would have been alive. And, I wish that people had a little, had more empathy for lives that were not like their own and for people who were genuinely in some kind of danger. Before they make narrow-minded pronouncements about immigrant populations.

The St. Louis was a ship of 937 men, women and child refugees fleeing the Nazis. The ship departed from Hamburg, Germany on 13 May, 1939 and was denied disembarkation in the United States and Cuba and was forced to return to Europe. Thomas and Witts (1974) wrote there were thirty million unemployed people in the United States and there was rampant xenophobia against immigrants. Also, in 1939, there were 4.5 million members of the Ku Klux Klan "Despite having descended from immigrant stock, they now regarded themselves 
as native Americans, and were determined to exclude anyone of doubtful origin" (p. 240). The authors cited Imperial Wizard Hiram W. Evans [who] explained: "The Negro is not a menace to Americanism in the sense that the Jew or Roman Catholic is a menace." Franklin Roosevelt, the President of the United States, was considered a liberal, but he was aware of the national sentiment and he returned the ship back to Germany.

There is profound irony in the rejection of the St. Louis given the inscription installed in 1903 on the Statue of Liberty in the New York Harbor. It is the sonnet The New Colossus written in 1883 by Jewish-American Emma Lazarus (1849-1887):

Not like the brazen giant of Greek fame, With conquering limbs astride from land to land; Here at our sea-washed, sunset gates shall stand A mighty woman with a torch, whose flame Is the imprisoned lightning, and her name Mother of Exiles. From her beacon-hand

Glows world-wide welcome; her mild eyes command The air-bridged harbor that twin cities frame. "Keep, ancient lands, your storied pomp!" cries she With silent lips. "Give me your tired, your poor, Your huddled masses yearning to breathe free, The wretched refuse of your teeming shore. Send these, the homeless, tempest-tossed to me, I lift my lamp beside the golden door! 
Lazarus wrote this sonnet as a response to the Russian pogroms against the Jewish people in 1881 which continued through 1884. The Russian Tsar Alexander II was assassinated in March 1881 by the revolutionary group Narodnaya Volya. Russian popular sentiment held the Jews responsible, thus, violence against the Jews. There were additional Russian anti-Jewish pogroms from 1903-1906 and again 1917-1922. Also the Armenian genocide in the Ottoman Empire in 1915 set a precedent for what would be later recognized as a genocidal war of extermination with a lack of global response. In 1939 Franklin Roosevelt made his decision to reject the St. Louis with the knowledge of recent history where millions had sought safe haven, particularly Jewish refugees.

Jewish people have historically had a tenuous position which most recently was brutally brought to light during the Holocaust. Jews have regularly been persecuted and/or expelled from many nations. From 1096 to 1349 there were numerous massacres of Jews in Germany beginning with the First Crusade (1095-1099). In 1182, Jews were expelled from France. In England in 1290, King Edward I issued the Edict of Expulsion which lasted through the Middle Ages. In 1492, the Alhambra Decree expelled Jews from Spain, which was not revoked until 1968.

Ben, David, Joseph, Marilyn, and Sarah, as well as, the other five participants want to see more Holocaust education for the general public. They are all aware of the current world conditions and having grown up under the shadow of the Holocaust, have frustration and fears for themselves and others. 
Hoffman (2004) tells us that current genocides, acts of terrorism, and traumas impact the second-generation with more force than they do others (p. 238). Nadine's concerns about United States immigration policies are founded in her knowledge of what immigration meant to the Jewish people during the Holocaust. At present, many people are fleeing their homelands for similar reasons, and many are being denied entry into the United States. This is distressing "common ground" to hold. 
Chapter 5 - Conclusion

This study is by no means definitive nor exhaustive. There is so much more to be said about the second-generation and the impact of the Holocaust. In the beginning of this study some non-Jewish people questioned the idea of this research and viewed it as irrelevant or unimportant as it happened so long ago, somewhere else, and to other people. But as hopefully outlined, this research is relevant and is about people who live here, wherever that may be. To bring this research paper to a conclusion we will briefly look at some of the findings, plus, look at some of the implications for the practice of Conflict Resolution.

If we recall Bellah et al.'s idea that a real community is a community of memory; we find that this is apparent in the participants' stories. Reading their words lends a very tangible sense of "contributions to a greater good" (2011, p. 229). And yet, there was the lone caller who said the Holocaust ruined her life, so she did not participate in this study. There are doubtless many others who are, perhaps, of families who may have been in Danieli's (1994) terms: "victim families" or "numb families." The families portrayed by the present study participants are "fighter families," and ultimately, "those who made it."

The emergent nine themes of disclosure, identity, loss, positive impact, negative impact, media, faith, education, and what others should know about being second-generation may offer insight into working with people experiencing inherited or intergenerational trauma. The most evocative question asked was for the participants to "describe their family." The ensuing revelations included the 
remarkable feats of those who died, of those who survived, and of the subsequent second-generation. It is suggested here that asking people to describe their families from the outset is vital for three reasons: to open the dialogue, to know the framework of their family, and as an expression of respect for the individual.

Resiliency and post-traumatic growth are apparent in the memories of the second-generation. An essential element for the participants in this study is that they grew up participating in the Jewish community both as practicing Jews and cultural Jews. We might resist the temptation to call a person either a practicing or cultural Jew. Someone like Ben, for example, might self-describe more as a cultural Jew, but he and his family keep the Sabbath and are practicing Jews. For the participants of this study, each person has spent a great deal of time and effort learning about the Holocaust not only from their parents, but from independent study as well. As noted, for the participants there never was a "before" the Holocaust. The Holocaust has always been part of their lives.

Laub (2006) writes eloquently on the need for Holocaust testimony (which we must add the importance of hearing from the subsequent generations as well). He says that personal experiences have added much needed connection and depth to the archival materials of documents, official correspondences, registries, and newspapers. Pertaining to the Holocaust survivors he says, "Testimony that could have given texture to the facts was treated as an unreliable source for the pursuit of historical truth" (p. 253). There is no better truth than interviewing the second- 
generation as to what the experience of growing up under the shadow of the Holocaust has been.

In their study on memory and resilience Cohen et al. (2010, p. 525) write:

The legacies of these [Holocaust] survivors reflect the importance of reconstructing family, transmitting values, contributing to the community, and educating the next generation. Survivors' ability to rebuild their lives after the Holocaust demonstrate that memory promoted resilience by enabling them to remember the past, to share their meaningful stories with others, to remember why and how they survived, and to find meaning in the aftermath of such injustice.

What people bring to the human dialogue are their memories, the memories of their families, and the memories of their extended families and community. It is important in conflict resolution studies that we examine the macro-level, but it is also very important that we examine the micro-level as each person, in any context, begins all interactions with their own personal expressions and manifestations of memory. We live our lives in the present tense, but always filtered through our memories and the knowledge we have of one another. The second-generation, for the most part, do not disclose their proximity to the Holocaust without deeper context and relationship with others. The participants have experienced the memory of the Holocaust in individual ways, yet collectively, they voice the need for education for all people. 
Hoffman (2004) writing about the events of September 11th, 2001, in New York City, said: "I had grown up with the subliminal expectation of catastrophe, and the "memory" of mass death in my very bones. And yet expectation is not the same as reality, received knowledge not the same as the direct kind" (p. 238). All of the participants of this study have the memory of trauma and growing up under its shadow. As mentioned before, Hoffman tells us that current genocides, acts of terrorism and traumas impact the second-generation with even more force than they do others as they have been previously targeted as Jews. With global terrorism on the rise, it is abundantly clear that state-sponsored terrorism creating genocides is a very dangerous and real concern for all people.

As noted, being second-generation is not generally openly stated by people, unless it is extremely significant to the setting, and we may not have the opportunity to learn from people without the auspices of conducting a study. When asked questions the participants responded frankly without hesitation, but in general they do not readily disclose. Nor should we expect them to. But here, we have the opportunity to listen to ten life stories and think about the intergenerational impact of trauma upon individuals and families which are the cornerstone of society. While this study was solely concerned with the aftermath of the Holocaust, the nine themes which emerged might be applicable to research into other genocides or perhaps assist in the conflict resolution practice when working with people with intergenerational trauma. 
Implications for Conflict Resolution

Implications of the current study for conflict resolution and conflict

transformation processes are these:

1. The weight of the processes may fall upon the descendants of trauma.

2. Everyone carries history.

3. Everyone has a story, which may be untold.

4. We may not know what is going to manifest rupture.

5. Survivors and their descendants may have more similarities than differences with survivors and descendants of other traumas and genocides.

6. The end of genocide requires people to engage with one another.

7. Dialogue groups may foster conflict transformation and peace-building.

There is another "second-generation" of the Holocaust: the children of the perpetrators. Berger and Berger (2001, p. 9) note a primary difference between the survivors' descendants and the perpetrators' descendants is that survivors descendants are trying to "connect" with the past, while perpetrators descendants are moving toward "rejection" of the repression of the past. These are separate trajectories, and yet, connected through history into the present day. Berger and Berger discuss the challenges of dialogues between these two groups of people. Some people see dialogue between each set of descendants as essential, whereas, others want nothing to do with it. The participants of the current study were not asked whether or not they would gain value in such dialogues. While there are many reasons for dissonance here a marked feature is the way these groups view their parents. The Jewish survivors descendants "can admire and respect their 
parents," whereas, the children of perpetrators "must live with the fact that their forebears either committed or acquiesced in evil" (Berger \& Berger, p. 335).

Tint (2009, p. 272) discusses dialogue groups as a method of bringing divergent parties into engagement with one another. Noting historical grievances, she says the conflict resolution and peacebuilding form "of dialogue differs from other kinds of dialogue in a number of ways":

1) "These processes are often laden with more traumatic and emotional content than those rooted in other issues. While it is not to be confused with therapy, dialogue of this nature does have a therapeutic and healing component that is not as fundamental to other intergroup processes."

2) "In most dialogue work associated with reconciliation, the fracture between groups is rooted squarely in the past. While any dialogue process will focus on certain dimensions of the past, dialogue around painful and conflicted histories demands that parties address past injuries as a primary focus of what has brought them together."

3) "In peace-building work, groups are brought together as a way of dealing with larger societal issues that impact almost all members of the groups. Members are attempting to simultaneously process both personal and structural dimensions of a pervasive phenomenon that they are often unable to influence; the focus then is on the individual experience of these large-scale issues."

4) "While some dialogue processes tend to develop spontaneously through what arises between parties when they come together with dialogic intent, dialogue work in deeply fractured societies typically requires a more focused or structured process to serve as 
a safe container for the deeply challenging issues that arise in the encounter."

The tenacity, perseverance, resiliency, and post-traumatic growth of the Jewish people has been developed over the millennia. The Holocaust was the most mechanized and bureaucratic assault against the Jews. It may not have been the last. In Berger's words: "Why the Jews?" No one seems to know. Jewish people represent less than $0.2 \%$ of the world population. When Jewish people say "Never Again," others need to say it as well. State-sponsored terrorism is a real concern as there is an intensifying worldwide shift to the far-right with rising xenophobia and nationalism potentially escalating conflicts, wars, and genocides. Thus, the current study has increasingly become more relevant for conflict resolution and conflict transformation.

Further research interviewing the Jewish second-generation is compelling and has significant value, but may not answer the looming question: How could the Holocaust have happened? How is it possible that the depraved inhumanity to others was acceptable to so many people? Therefore, I believe future research should be conducted into those populations holding far-right, xenophobic, or nationalistic positions. Something is happening in the United States, France, Greece, Hungary, Italy, Romania, Sudan, Syria, and other nations, along a continuum of a political shift to the far-right, closing the borders to immigration, ethnic cleansing, and genocide. As conflict resolution and conflict transformation 
practitioners, we must identify, study, and educate would-be perpetrators before the act. Intervention is crucial for peacemaking and our survival. 


\section{References}

Ball, K. (2015). [Review of the book Popular trauma culture: Selling the pain of others in the mass media, by A. Rothe]. Film \& History: An Interdisciplinary Journal, 45, 1, 88-90.

Bar-Tal, D. (2003). Collective memory of physical violence: Its contribution to the culture of violence. In Cairns, E. \& Roe, M. D. (eds.) (2003). The role of memory in ethnic conflict. New York, NY: Palgrave Macmillan, p. 77-93.

Bellah, R., Madsen, R., Sullivan, W.M., Swidler, A. \& Tipton, S.M. (2011). "From Habits of the heart: Individualism and commitment in American life. In Olick, J., Vinitzky-Seroussi, V. \& Levy, D. (Eds.) The collective memory reader (p. 229-230). Oxford, UK: Oxford University Press.

Berger, A. L. (1997). Children of Job: American second-generation witnesses to the Holocaust. New York, NY: State University of New York Press.

Berger, A.L. \& Berger, N. (Eds.). (2001). Second generation voices: Reflections by children of Holocaust survivors \& perpetrators. Syracuse, NY: Syracuse University Press.

Bergmann, M. S. \& Jucovy, M. E. (Eds.). (1982). Generations of the Holocaust. New York, NY: Basic Books. 
Bigsby, C. (2006). Remembering and imagining the Holocaust: The chain of memory. Cambridge, UK: Cambridge University Press.

Brison, S.J. (1999). Trauma narratives and the remaking of the self. In Bal, M, Crewe, J. \& Spitzer, L., (Eds.) Acts of memory: Cultural recall in the present (37-54). Hanover, CT: University Press of New England.

Booth, J.W. (2006). Communities of memory: On witness, identity, and justice. Ithaca, NY: Cornell University Press.

Bukiet, M. J. (Ed.) (2002). Nothing makes you free: Writings by descendants of Jewish Holocaust survivors. New York, NY and London, UK: W. W. Norton \& Company.

Cairns, E. \& Roe, M. D. (eds.) (2003). The role of memory in ethnic conflict. New York, NY: Palgrave Macmillan.

Cohen, H. L., Meek, K. \& Lieberman, M. (2010). Memory and resilience. Journal of Human Behavior in the Social Environment, 20, 525-541.

Creswell, J. W. (2009). Research design: Qualitative, quantitative, and mixed methods approaches (3rd edition). Los Angeles, CA and London, UK: Sage

Creswell, J. W. (2013). Qualitative inquiry \& research design: Choosing among five approaches. Los Angeles, CA and London, UK: Sage. 
Danieli, Y. (1994). As survivors age: Part I. National Center for PTSD Clinical Quarterly, 4 (1), 3-7.

Dash Moore, D. (2004). GI Jews: How World War II changed a generation. Cambridge, MA: Harvard University Press.

Dawidowicz, L. S. (1975). The war against the Jews 1933-1945. New York, NY: Holt, Rinehart and Winston.

Des Pres, T. (1980). The dreaming back. Centerpoint, 4, 13-18.

Engelking, B. (2001). Holocaust and memory: The experience of the Holocaust and its consequences: An investigation based on personal narratives. London, UK: Leicester University Press.

Epstein, H. (1979). Children of the Holocaust: Conversations with sons and daughters of survivors. New York, NY: G. P. Putnam's Sons.

Finkelstein, N. (January 01, 2000). The Holocaust industry. Index on Censorship, 29, 120-129.

Fogu, C. \& Kansteiner, W. (2006). Politics of memory, poetics of history. In Lebow, R.N., Kansteiner, W. \& Fogu, C. (Eds.) The politics of memory in postwar Europe (p. 284-310). Durham, SC: Duke University Press.

Frankl, V. E. (1946). Man's search for meaning. Boston, MA: Washington Square Press. 
Gangi, S., Talamo, A., \& Ferracuti, S. (January 01, 2009). The long-term effects of extreme war-related trauma on the Second-generation of Holocaust survivors. Violence and Victims, 24, 5, 687-700.

Giorgi, A. (2009). The descriptive phenomenological method in psychology: A modified Husserlian approach. Pittsburg, PA: Duquesne University Press.

Gitelman, Z. (2003). Collective memory and contemporary Polish-Jewish relations. In Zimmerman, J.D. (Ed.), Contested memories: Poles and Jews during the Holocaust and its aftermath. New Brunswick, NJ: Rutgers University Press.

Gross, A. S., \& Hoffman, M. J. (June 17, 2004). Memory, authority, and identity: Holocaust studies in light of the Wilkomirski debate. Biography, 27, 1, 2547.

Gurfinkiel, M. (August 2013). You only live twice: Vibrant Jewish communities were reborn in Europe after the Holocaust. Is there a future for them in the 21st century? Mosaic: Advancing Jewish Thought, August 2013. Retrieved from http://mosaicmagazine.com/essay/2013/08/you-only-livetwice

Halbwachs, M. (1992). On collective memory, Coser, L.A. (Ed.). Chicago: The University of Chicago Press. 
Hansen, M. B. (January 01, 1996). Schindler's list is not Shoah: The second commandment, popular modernism, and public memory. Critical Inquiry, $22,2,292-312$.

Hass, A. (1990). In the shadow of the Holocaust: The second-generation. Cambridge, UK: Cambridge University Press.

Hocker, J. L. \& Wilmot, W. W. (2014). Interpersonal Conflict, 9th ed. New York, NY: McGraw-Hill.

Hoffman, E. (2004). After such knowledge: Memory, history, and the legacy of the Holocaust. New York, NY: Public Affairs.

Husserl, E. (1970). The crisis of European sciences and transcendental phenomenology. (D. Carr, Trans.). Evanston, IL: Northwestern University Press.

Itkoff, S., Leth, K., and Ogris, K. (producers) \& Shamir, Y. (director). (2009). Defamation [motion picture]. United States: First Run Features.

JTA. (11 January 2015). 'France will no longer be France if Jews leave.' Retrieved from http://www.jta.org/2015/01/11/news-opinion/world/ifjews-leave-france-will-no-longer-be-france-foreign-ministersays\#ixzz3OaMY9snt 
Kellerman, N. P. F. (2001). Psychopathology in children of Holocaust survivors: A review of the research literature. Israel Journal of Psychiatry \& Related Sciences, 38, 1, 36-46.

Kertész, I., \& MacKay, J. (April 01, 2001). Who owns Auschwitz? Yale Journal of Criticism, 14, 1, 267-272.

Kestenberg, J. S. (1982). Survivor-parents and their children. In M. S. Bergmann \& M. E. Jucovy (Eds.), Generations of the Holocaust, pp. 83-101. New York: Basic Books.

Klein-Parker, F. (1984). Dominant attitudes of adult children of Holocaust survivors towards their parents. Dissertation. Saybrook Institute.

Kraft, R. N. (June 01, 2006). Archival memory: Representations of the Holocaust in oral testimony. Poetics Today, 27, 2, 311-330.

LaCapra, D. (January 01, 1997). Lanzmann's Shoah: "Here There Is No Why". Critical Inquiry, 23, 2, 231-269.

Landsberg, A. (1997). America, the Holocaust, and the mass culture of memory: Toward a radical politics of empathy. New German Critique, 71, 63-86.

Lang, B. (January 01, 1996). Holocaust memory and revenge: The presence of the past. Jewish Social Studies, 2, 2, 1-20.

Lang, B. (May 01, 2010). Six questions on (or about) Holocaust denial. History and Theory, 49, 2, 157-168. 
Langer, L. L. (1991). Holocaust testimonies: The ruins of memory. New Haven \& London: Yale University Press.

Laub, D. (1989). Failed empathy - A central theme in the survivor's Holocaust experience. Psychoanalytic Psychology, 6, 4, 377-400.

Laub, D. (1992). Bearing witness: Or the vicissitudes of listening, p. 57-74. In Felman, S. and Laub, D. Testimony: Crises of witnessing in literature, psychoanalysis, and history. New York, NY: Routledge.

Laub, D. (1998). The empty circle: Children of survivors and the limits of reconstruction. Journal of the American Psychoanalytic Association, 46, 507-529.

Laub, D. (2006). From speechlessness to narrative: The cases of Holocaust historians and of psychiatrically hospitalized survivors. Literature and Medicine, 24, 2, 253-265.

Lederach, J. P. (2003). The little book of conflict transformation. Intercourse, PA: Good Books.

Lemkin, R. (1944, 1973). Axis rule in occupied Europe. New York, NY: Howard Fertig, Publisher.

Levy, D., \& Sznaider, N. (January 01, 2002). Memory unbound: The Holocaust and the formation of cosmopolitan memory. European Journal of Social Theory, 5, 1, 87-106. 
Mangione, S. (2013). Nazi medicine, collective evil, and the role of physicians during the Holocaust. Lecture. 27 August 2013. Portland, OR.

Moustakas, C. (1994). Phenomenological research methods. Thousand Oaks, CA \& London, UK: Sage Publications.

Nadler, A., Kav-Venaki, S., \& Gleitman, B. (January 01, 1985).

Transgenerational effects of the Holocaust: externalization of aggression in second-generation of Holocaust survivors. Journal of Consulting and Clinical Psychology, 53, 3, 365-9.

Nora, P. (2011). Reasons for the current upsurge in memory. In Olick, J., Vinitzky-Seroussi, V. \& Levy, D. (Eds.) The collective memory reader (p. 437-441). Oxford, UK: Oxford University Press.

Olick, J.K., Vinitzky-Seroussi, V \& Levy, D. (2011). The collective memory reader. Oxforf, UK: Oxford University Press.

Oppenheimer, L. and Hakvoort, I. (2003). Will the Germans ever be forgiven? Memories of the Second World War four generations later. In Cairns, E. \& Roe, M. D. (eds.) (2003). The role of memory in ethnic conflict. New York, NY: Palgrave Macmillan, p. 94-103.

Pelley, S. (June 25, 2007). "Hitler's secret archive." CBS News: 60 Minutes [video]. Retrieved from: http://www.cbsnews.com/videos/hitlers-secretarchive/ 
PEW Forum. (1 October 2013). A portrait of Jewish Americans. Findings from a PEW Research Center Survey of U.S. Jews. Retrieved from: http://www.pewforum.org/files/2013/10/jewish-american-survey-fullreport.pdf

Radstone, S. (2008). Memory studies: For and against. Memory Studies, 1, 1, 3140.

Ricoeur, P. (2004). Memory, history, forgetting. Chicago, Il: University of Chicago Press.

Scharf, M., \& Mayseless, O. (January 01, 2011). Disorganizing experiences in second- and third-generation Holocaust survivors. Qualitative Health Research, 21, 11, 1539-1553.

Schweber, S. (2006). "Holocaust Fatigue": Teaching it today. Social Education, $70,1,48-55$.

Sigal, J. J. \& Weinfeld, M. (1989). Trauma and rebirth: Intergenerational effects of the Holocaust. New York, NY: Praeger Publishers.

Sorscher, N. \& Cohen, L. J. (1997). Trauma in children of Holocaust survivors: Transgenerational effects. American Journal of Orthopsychiatry, 6, 3, 493-500. 
Spielberg, S. (executive producer) \& János Szász (director). (2002). "Eyes of the Holocaust" in Broken Silence [motion picture]. United States: Cinemax and Shoah Visual History Foundation.

Spielberg, S., Lustig, B. \& Molen, G.R. (producers) \& Spielberg, S. (director). (1993). Schindler's List [motion picture]. United States: Universal.

Stein, A. (January 01, 2009). Trauma and origins: Post-Holocaust genealogists and the work of memory. Qualitative Sociology, 32, 3, 293-309.

Stein, A. (2014). Reluctant witnesses: Survivors, their children, and the rise of Holocaust consciousness. New York, NY: Oxford University Press.

Tauber, Y. (January 01, 2003). We're listening, but can we hear? Psychotherapy with Holocaust survivors and the second-generation in Israel, under (threat of) conditions of armed conflict. Journal of Trauma Practice, 2, 1, 17-46.

Tedeschi, R. G. \& Calhoun, L. G. (2004). Posttraumatic growth: Conceptual foundations and empirical evidence. Psychological Inquiry, 15, 1-18.

Thomas, G. \& Witts, M.M. (1974). Voyage of the Damned. Old Saybrook, CT: Konecky \& Konecky.

Tint, B. (2003). Collective memory and Conflict Resolution. Dissertation. University of Melbourne.

Tint, B. (June 07, 2010a). History, memory and intractable conflict. Conflict Resolution Quarterly, 27, 3, 239-256. 
Tint, B. (June 07, 2010b). History, memory, and Conflict Resolution: Research and application. Conflict Resolution Quarterly, 27, 4, 369-399.

Tint, B. S. (2009). From "Dialogue, forgiveness, and reconciliation." In Kalayjian, A. \& Paloutzian, R. F. (Eds.) Forgiveness and reconciliation: Psychological pathways to conflict transformation and peacebuilding. Springer: Peace Psychology Book Series.

Tulving, E. (1983). Elements of episodic memory. New York: Oxford University Press.

United States Department of Health, Education and Welfare. (1950). Vital statistics of the United States: 1950. Retrieved from http://www.cdc.gov/nchs/data/vsus/vsus_1950_1.pdf

van Manen, M. (1990). Researching lived experience: Human science for an action sensitive pedagogy. New York, NY: State University of New York Press.

Zerubavel, E. (2011). From "Social memories: Steps toward a sociology of the past." In Olick, J., Vinitzky-Seroussi, V. \& Levy, D. (Eds.) The collective memory reader (p. 221-224). Oxford, UK: Oxford University Press. 


\section{Appendix A - Interview Questions}

1. Please describe your family.

2. How old were you when you learned your parent(s) had been affected by the Holocaust?

3. Did your parent(s) tell you first or did you learn about the Holocaust from others?

4. What is your reaction when you hear the word Holocaust being used to define other historical and/or current events?

5. What is the hardest aspect of being a second-generation survivor?

6. When you meet someone new when, if you do, do you disclose you are of the second-generation?

7. What do you wish others knew about being a second-generation survivor?

8. How have your parent(s) memories shaped who you are? 


\title{
Appendix B - IRB Approved Consent Form - Video
}

\author{
Holocaust, Memory, Second-Generation and Conflict Resolution - Video Responses
}

Dear

My name is Leslie O'Donoghue, and I am a student at Portland State University. I am beginning a study on Second-Generation Survivors, and would like to invite you to participate.

You are being asked to take part because you are a Second-Generation Survivor. As part of the study, I am interested in your opinions and attitudes about the Holocaust and Memory, and hope that the information I collect will help us to better understand the effects of the Holocaust on subsequent generations. If you decide to participate, you will be asked to participate in a videotaped interview, which involves answering questions about your family and your experiences as the child of either one or two Survivors. It should take approximately an hour or two to complete. The interview tapes will be stored at PSU in the Conflict Resolution department.

As a result of this study, you may experience strong emotions. However, I assure you that we will conclude the interview at any time you wish to stop. You may not receive any direct benefit from taking part in this study, but the study may help to increase knowledge that may help others in the future.

Any information that is obtained in connection with this study and that can be linked to you or identify you will be kept confidential, unless you specifically agree to be identified in my thesis by first name and last initial. In addition, you will be asked whether or not you consent to have the video to be available for future researchers and/or presentation at academic conferences. If you do not consent, there is no negative effect and your wishes, as to whether or not others can view your interview, will be final.

Participation is entirely voluntary. Your decision to participate or not will not affect your relationship with the researcher or with Portland State University in any way. If you decide to take part in the study, you may choose to withdraw at any time without penalty. Please keep a copy of this letter for your records.

If you have questions or concerns about your participation in this study, contact Leslie O'Donoghue at PO Box 1093, Rainier, OR 97048 or by phone (503) 432-5053. If you have concerns about your rights as a research subject, please contact Research and Strategic Partnerships, Market Center Building $6^{\text {th }}$ floor, Portland State University, (503) 725-4288.

Sincerely,

Leslie O'Donoghue

Portland State University

Your signature indicates that you have read and understand the above information and agree to take part in this study. The researcher should provide you with a copy of this form for your own records.

Signature

No

\section{Printed Name}

First name and initial? Yes No 


\title{
Appendix C - IRB Approved Consent Form - Written
}

\author{
Holocaust, Memory, Second-Generation and Conflict Resolution - Written Responses
}

Dear

My name is Leslie O'Donoghue, and I am a student at Portland State University. I am beginning a study on Second-Generation Survivors, and would like to invite you to participate.

You are being asked to take part because you are a Second-Generation Survivor. As part of the study, I am interested in your opinions and attitudes about the Holocaust and Memory, and hope that the information I collect will help us to better understand the effects of the Holocaust on subsequent generations. If you decide to participate, you will be asked to provide written responses, which involves answering questions about your family and your experiences as the child of either one or two Survivors. The written responses will be stored at PSU in the Conflict Resolution department.

As a result of this study, you may experience strong emotions. However, I assure you that we will conclude the interview at any time you wish to stop. You may not receive any direct benefit from taking part in this study, but the study may help to increase knowledge that may help others in the future.

Any information that is obtained in connection with this study and that can be linked to you or identify you will be kept confidential, unless you specifically agree to be identified in my thesis by first name and last initial. In addition, you will be asked whether or not you consent to have the video to be available for future researchers and/or presentation at academic conferences. If you do not consent, there is no negative effect and your wishes, as to whether or not others can view your interview, will be final.

Participation is entirely voluntary. Your decision to participate or not will not affect your relationship with the researcher or with Portland State University in any way. If you decide to take part in the study, you may choose to withdraw at any time without penalty. Please keep a copy of this letter for your records.

If you have questions or concerns about your participation in this study, contact Leslie O'Donoghue at PO Box 1093, Rainier, OR 97048 or by phone (503) 432-5053. If you have concerns about your rights as a research subject, please contact Research and Strategic Partnerships, Market Center Building $6^{\text {th }}$ floor, Portland State University, (503) 725-4288.

Sincerely,

Leslie O'Donoghue

Portland State University

Your signature indicates that you have read and understand the above information and agree to take part in this study. The researcher should provide you with a copy of this form for your own records.

Signature

Printed Name
Date

Written Responses available to others? Yes No

First name and initial? Yes No 